Sergio Zañartu U., s.j.

Profesor de la Facultad de Teología

Pontificia Universidad Católica de Chile

\title{
Presentación de algunos aspectos de la Trinidad en los discursos teológicos de Gregorio de Nacianzo
}

\section{INTRODUCCIÓN}

Este trabajo solo se refiere directamente a las Orationes 27 a 31, pronunciadas por Gregorio en 380 para defender la doctrina trinitaria (1), sobre todo contra los eunomianos (2). Lo realizo desde mis inquietudes y preguntas como profesor de dogma. El texto lo tomo de la edición de P. Gallay en Sources Chrétiennes, vol. 250. Tengamos presente que se trata de piezas de oratoria, con polémica, interrogaciones, respuestas ad hoc que quizás no siempre le satisfacen del todo, etc. Es un estilo movido (3).

(1) Véase De vita sua, 1059, 1100; 1020; 1852-1854; 1947s; Carm II, 1, 16, 29, PG 37, 1256. Cuando llegó a Constantinopla, se lo creyó politeísta (De vita sua, 652-659). Cf. Ep 100, 2.

(2) No entro en el problema de si la Orat 28 fue añadida después a la colección o no. Según Francesco Trisoglio (Gregorio di Nazianzo il teologo [Studia Patristica Mediolanensia, 20], Milano 1996, p. 45), "L'inattessa missione costantinopolitana (inizio 379- metà 381), nonostante la sua fuggevolezza, finì per diventare il culmine e la fioritura più rigogliosa della vita di Gregorio, sia sotto l'aspetto dell'azione ecclesiastica, che del magisterio teologico, che dell'attività oratoria (vi pronunciò 22 dei 44 discorsi che abbiamo)". Este mismo autor en su conclusión traza un esbozo de su personalidad. Respecto a los estudios sobre Gregorio, se puede consultar, S. Bergmann, Geist, der Natur befreit. Die trinitarische Kosmologie Gregors von Nazianz im Horizont einer ökologischen Theologie der Befreiung, Mainz 1995, pp. 31-49.

Fr. Courth (Trinität in der Schrift und Patristik [Handbuch der Dogmengeschichte II, 1a], Freiburg 1988 p. 180) dice, entre otras cosas, al terminar su presentación de Gregorio: "Die spezifischen Akzente, die Gregor in den Sammelbegriff 'Trinitätslehre der Kappadozier' einbringt, liegen zum einen auf der formal-begrifflichen Ebene. Mit seinem Ringen um die angemessene sprachlich-bekenntnishafte Ausdrucksform des nizänischen Glaubens und seiner pneumatologischen Entfaltung hat er wesentlich mit dazu beigetragen, diesem endlich zum Durchbruch zu verhelfen. Ein konsequenterer Blick noch als bei Basilius kommt ihm bezüglich des H1. Geistes zu, der nicht nur göttlichen Wesens, sondern zugleich eine eigene göttliche Hypostase ist. Sein sprachliches Aneignungsbemühen gerade auch der immanenten Trinitätslehre ist von einem doppelten Anliegen bestimmt, einem soteriologischen und einem doxologischen. Im Trinitätsbekenntnis geht es nach Gregor wesentlich um das Heil des Menschen, was zuvor schon verstärkt Athanasius und dann auch Basilius in die antihäretische Auseinandersetzung eingebracht hatten. In der Verbundenheit mit ihnen betont Gregor den inneren Zusammenhang von Trinitäts- und Christusbekenntnis mit der Heilsfrage derart, dass man auch hier von einer ausgeprägten Note seiner Theologie sprechen kann".

(3) Sobre su estilo en general, puede consultarse F. Trisoglio, op. cit., cap. IV. 
Como Gregorio dirá después (4), él nunca ha preferido nada a la fe de Nicea. En ella se afirmó que el Hijo era consubstancial con el Padre. Ahora agrega que también el Espíritu es Dios (5), es decir consubstancial, cuestión que en tiempo de Nicea no se agitaba (6). Por tanto, el Padre, el Hijo y el Espíritu Santo son de una sola Divinidad. Y combatir a uno de ellos, es combatir la divinidad, porque Dios sería incompleto e imperfecto (7). Así brilla la afirmación de la Trinidad en su luz deslumbradora, como en tres soles que se compenetran mutuamente única es la fusión (súgkrasis) de la luz (8). Los tres son luz: luz y luz y luz, pero una sola luz, un solo Dios (9). "De la luz (el Padre) captamos la luz (el Hijo) en la luz (el Espíritu Santo)” (10). Este sería el momento teológico. La divinidad del Espíritu lleva a que la Trinidad resplandezca con más brillo, o quizás, mejor traducido (11), resplandezca para almas más ilustres (12). Se produce como un deslumbramiento entre la unidad y la Trinidad (13): "Cuando, pues, por una parte miramos a la divinidad y a la causa primera y a la monarquía, se nos aparece lo uno, pero cuando miramos, por otra parte, hacia aquellos en los que está la divinidad y los que vienen de la primera causa atemporalmente y con igual gloria, adoramos a tres" (14). Si se lo quiere expresar brevemente: divinidad sin división en los distintos (améritos en memerisménois) (15).

(4) Ep 102,1.

(5) Gregorio ya lo había afirmado mucho antes, p. e. en la Orat 12, 6. En Orat 43, 68s defiende a Basilio, quien no dijo que el Espíritu era Dios, pero usó téminos equivalentes de la Escritura, muchas veces lo proclamó públicamente y confió a Gregorio el hacerlo abiertamente. Véase Ep 58. En 31,10.11.29 aplica homooúsion al Espíritu.

(6) Ep 102, 2

(7) Cf. 31, 4. Véase 29, 17.

(8) 31, 14. Véase 31, 28.

(9) "Dios, Dios mío y Dios, mónada trina" (Carm II, 1, 14, 42, PG 37, 1248).

(10) 31, 3. A esto lo llama "teología [texto preferido por Gallay] breve y simple de la Trinidad" (Ib.). Cf. Sal 36, 10 (numeración hebrea). Véase, p. e., Basilio, De Spiritu Sancto, XVIII, 47, 1-21.

(11) eklámpsei toîs lamprotérois.

(12) 31, 26. Cf. L. Wickham y F. Williams, en Faith Gives Fullness to Reasoning. The Five Theological Orations of Gregory Nazianzen, con introducción y notas de F. W. Norris (Supplements to Vigiliae Christianae, 13), Leiden 1991.

(13) Respecto a una comparación de la Trinidad, que le atrae pero critica, dice: "no siendo uno más que muchos ni muchos más que uno" (31, 32). El deslumbramiento entre los dos polos de Gregorio es reforzado por la lucha contra los dos extremos: sabelianos y arrianos.

(14) 31, 14. Véase p. e. Orat 40, 41 ("no alcanzo (ou ftháno) a pensar lo uno y estoy rodeado del esplendor de los Tres; no alcanzo a distinguir los tres y ya soy conducido a lo uno"). P. Gallay (Grégoire de Nazianze. Discours 27-31. Introduction, texte critique, traduction et notes, [SC 250], Paris 1978, p. 300 n. 3) afirma: 'L' unité de Dieu, c' est, pour la foi de Nicée, l' unité du Père, de qui procède le Fils consubstantiel, dans l' Esprit. Cette foi au Dieu unique, Père de Notre-Seigneur Jésus-Christ, est bien celle qui, dès les origines, a écarté tout soupçon d' édulcoration du monothéisme. Mais le problème se pose d' une manière nouvelle si l' attention se porte sur 1' unité de Dieu fondée sur l'égale dignité et la parfaite divinité des trois. C' est ce problème qu' aborde ici $[31,13]$ Grégoire de Nazianze".

(15) $I b$. "Adorando al Padre y al Hijo y al Espíritu Santo. Reconociendo en el Hijo al Padre, en el Espíritu al Hijo, en los que hemos sido bautizados, en los que hemos creído, con los que nos hemos alineados, distinguiendo antes de unir, y uniendo antes de distinguir (prìn sunápsai diairoûntes, kaì prìn dieleîn sunáptontes), no los tres como uno (porque no son los nombres sin hypostasis [anupóstata], o al interior de una hypóstasis [katà miâs hupostáseos], como si la riqueza para nosotros estuviera en los nombres y no en las realidades [prágmasi]), y los tres uno. En efecto, no por la hypóstasis sino por la divinidad, la mónada es adorada en la Trinidad y la Trinidad recapitulada en (eis) la mónada" $(6,22)$. "Pongamos en la cabeza de este discurso al Padre y al Hijo y al Espíritu Santo, sobre los que es el discurso, de forma que el primero sea 
Gregorio quiere, dejando a un lado las imágenes de la Trinidad, que son engañosas (16), atenerse a lo más piadoso, apoyándose en pocas palabras, tomando al Espíritu como guía, guardando hasta el final la iluminación recibida en el bautismo, compañera de nacimiento y socia (17). La forma piadosa llega a confundirse con ortodoxa (18). Los adversarios son impíos (19): hombres de muchas palabras y de razonamientos falsos e insidiosos (20). "Porque cuando ponemos por delante el poder del razonamiento dejando de lado el creer (21), y cuando con nuestras búquedas destruimos la credibilidad del Espíritu y entonces el discurso pasa a ser inferior a la grandeza del asunto -y será del todo inferior procediendo del débil órgano de nuestra inteligencia-, ¿qué sucede entonces? La debilidad del discurso se presenta como misterio. Y así la sutileza del discurso proclama el vaciamiento de la cruz, como opina también Pablo. Porque la fe es la plenificación de nuestra razón (lógou)" (22).

benevolente (eudokeîn), el segundo coopere (sunergeîn [véase 30, 3.5]) y el tercero inspire (empneîn), o más bien que se haga una única iluminación de la única divinidad, unitariamente distinta y distintamente reunida (henikôs diairouménen kaì sunaptoménen diairétos), lo que es paradójico" (28, 1 ; cf. 23, 8). Dice, contrastando el Creador con la creatura, en Orat 34, 8: "Lo primero se llama Dios, aunque consiste en los Tres grandísimos, la Causa, el Demiurgo y el que hace perfecto (teleiopoi $\hat{\mathbf{o}}_{\mathbf{i}}$ ) (véase, p. e. Orat 38, 9; 41, 9.11; Basilio, De Spiritu Sancto, XVI, 38, 13-15, etc), yo digo el Padre y el hijo y el Espíritu Santo. ...es más uno (henikotéra) que lo del todo divisible y más rico que lo perfectamente mónada". Cf. p. e. Orat 23, 8; 25, 17; ; 26, 19; 39, 11. Respecto a la paradoja trinitaria opina T. A. Noble (Paradox in Gregory Nazianzen's Doctrine of the Trinity, p. 99) en Studia Patristica 27, pp. 94-99) lo siguiente: "In other words, Gregory deliberately embraces paradox: two different models, each with its own logic apparently incompatible with the other, but both of wich are required to do justice to the mystery of the Trinity. The Father is greater (as Author, aítios), yet he is not greater (in nature); the Father is Cause (or Author, aitíos) and Origin (arjéé), yet the one God is Cause (he próte aitía); God is Three, yet God is One. Gregory attempts in this way to rise above the division between Origenists and Nicenes with an ecumenical doctrine of the Trinity which united all the orthodox by a use of paradox which alone could express the Mystery". Respecto a la creación trinitaria, puede verse Bergmann, op. cit., 116s.

(16) Se ha mostrado crítico respecto a ellas (31,31-33). Así dice en 31, 10 que buscar la semejanza en las cosas de aquí abajo y que nos conciernen, tomar lo de aquí abajo, lo que tiene naturaleza inconstante, como imagen de lo de arriba, de lo inmutable, es muy vergonzoso y suficientemente alocado, como buscar los vivos entre los muertos. Sin embargo, pone una comparación; pero después añade, que esto lo hace como contemplando, sobre una escena, los inteligibles. Porque nada de lo comparado puede alcanzar toda la verdad en su pureza (31, 11; véase Orat 23, 11, donde compara con el noûs, lógos y pneûma; cf. Orat 12,1). Solo se puede tomar un trazo de la imagen $(31,33)$; algo pequeño de la semejanza $(31,31)$. Véase 29,2 . Aun los nombres como 'Hijo' hay que aplicarlos metafóricamente $(31,7)$. Véase 31,12 (mikràn tês henóseos fantasían)

(17) 31,33 . Véase 31,$17 ;$ p. e. Orat 33,$17 ; 34,11 ; 40,41$

(18) 28,$2 ; 29,1.18 ; 30,12.15 ; 31,5.33$. Cf. 27, 5. Gregorio se conmueve al ver cómo es tratado nuestro gran misterio $(27,2)$. Cf. $31,29$.

(19) $27,2.7 .9 ; 31,1.2 .3 .12 .13 .21 .30$. Véase $29,10.14 .16$, etc. Los silogismos del adversario destruyen la fe y vacian el misterio $(31,23)$.

(20) 27 íntegro; 29, 1.9.15.21; 31, 7.13.23, etc. Tienen exagerada confianza en los recursos lógicos $(28,7)$. Véase 27,$2 ; 29,8.21$. Van a ser llamados bestias salvajes $(31,1)$, jabalí furioso $(31,20)$. Véase 27,$9 ; 28,2$. Estas discusiones le producen repugnancia a Gregorio $(31,2)$, quien respeta al Logos (27, 5). Véase 28, 11.

(21) En los misterios de las cosas celestiales, habiendo la razón reconocido que hay cosas que la superan, desea que nos conduzca más la fe que la razón $(28,28)$

(22) 29, 21 (por eso no deben extinguir el Espíritu sino ser iluminados por él; las indagaciones pueden destruir la autoridad del Espíritu). Cf. 30, 1; 31, 2.7.13.20.23.24.29, etc. 
Lo que se necesita para tratar de la divinidad, para la teología, es purificarse (23) para que la luz sea captada por la luz (24), avanzar en contemplación (25). Hay que subir a la montaña y penetrar en la nube (26), alejándonos de la materia (27). Lo que nos separa de Él es la tiniebla corporal (28). Y mientras más se avanza, más se nos escapa la sabiduría (29). "Asemejándose" a Dios se lo conoce mejor (30). Al final conoceremos como somos conocidos (31). El alejarse de lo material para subir a lo de arriba está subtendido por un contraste platónico (32) entre el mundo de los sentidos (corporal) y el de lo inteligible (tò nooúmenon) que es lo invisible y pariente de nuestro noûs (33). Esto no obsta para admirar la creación en 28, 22-31, que canta la gloria del Creador.

A Dios no lo podemos mirar directamente, sino en sus creaturas. A lo más, con dificultad, su espalda (tà opísthia) (34), es decir la grandeza de Dios en las creaturas producidas y gobernadas. Es como ver las sombras del sol en las aguas. Ni siquiera lo celestial y supracelestial, que están más distantes de Él que lo que están por sobre nosotros, pueden comprenderlo perfectamente (teleías katalépseoss) (35).

(23) 27, 3.4.7; 28, 2.12; 29, 11; 30, 20 (lógo $\underline{\mathbf{o}}_{\mathbf{i}} \mathbf{k a i ̀ ~ b i ́ \mathbf { ~ }} \underline{\mathbf{i}}_{\mathbf{i}) .}$. Hay que hablar santamente de lo santo $(27$, 5), ser puro para tocar la pureza $(27,3$; véase 30,20$)$. Según 30,10 , los purificados por el Logos (véase también 30,20$)$, los que lo captan con el noûs, no necesitan ayunar ante la presencia del esposo.

(24) $28,1$.

(25) 27, 3 (theoría $\mathbf{a}_{\mathbf{i}}$ ). Teniendo el pensamiento (noûn) de Dios (28, 9). Cf. 28, 2.12.21.

(26) 28, 2.3. Véase 29,$8 ; 31,1$

(27) Cf. 28, 3 (los ángeles están más cerca de nosotros que de Dios); 29, 11

(28) 28, 12. Véase 28,11. "Esta tiniebla y este espesor carnal intercepta la inteligencia de lo verdadero" $(28,4)$. No hay manera para los que están en cuerpo de estar del todo con lo espiritual (t $\mathbf{n}$ noouménon) sin lo corporal" $(28,12)$. No podemos sobrepasar nuestra propia sombra $(28,17)$. No podemos encontrar estas realidades desnudas con nuestra inteligencia (noï) desnuda, para que esta fuera marcada por estas percepciones $(28,21)$. Todo el conocimiento (gnôsin) de aquí abajo, según Pablo, no va más allá de los espejos y de los enigmas, como detenido en pequeñas apariencias de la verdad $(28,20)$

(29) 28, 21. Véase Orat 2, 76.

(30) Véase 28, 4.12. Cf. 30, 19.

(31) 28, 17. Lo descubriremos cuando nuestro espíritu (noûn) y razón, que es semejante a Dios y divino, se mezcle con su familiar (oikeío $\underline{i}_{\text {) }}$, cuando la imagen sea ascendida al arquetipo, al que tiende ahora $(28,17)$. Entonces se disiparán para nosotros las tinieblas y nuestro espesor $(29,11)$. Lo que el mundo de aquí abajo no puede contener, un día podrá ser llevado y aclarado $(28,20)$. Seremos íntegramente semejantes a Dios (theoeideîs); lo podremos contener (jọretikoí) íntegro (hólou) y a Él solo: esto es la perfección $(30,6)$. Será otro terremoto (como lo fue la Ley, el Antiguo Testamento; y el Evangelio, el Nuevo Testamento) el paso de las cosas de aquí a las de allá, que no serán más removidas ni sacudidas $(31,25)$. Véase 27,$10 ; 29,19$.

(32) El contraste en estos textos no está entre creatura y creador, sino entre sensible e inteligible. " El sol es entre lo sensible lo que es Dios entre lo inteligible', dijo uno que no es de los nuestros [Platón, República VI, 508c]. Porque uno ilumina el ojo, como el otro la inteligencia (noûn). Aquel es lo más hermoso de lo visible, como este de lo inteligible" $(28,30)$. En 29, 19, respecto a Cristo, Gregorio increpa: “¿cómo tropiezas con lo visible no atendiendo a lo inteligible”. Cf. 29, 18 (subir con la divinidad [de Cristo] hacia lo inteligible y conocer lo que corresponde a la naturaleza divina). En 30, 15 la contraposición es entre fainómenon e inteligible (aplicada a Cristo). Nuestros cuerpos y almas (psujaîs) siempre están fluyendo y cambiando $(31,15)$.

(33) 28, 12.21 (aisthéseon, noêtoîs). En 28, 31 se habla de sobrepasar la sensación para asomarnos a mirar hacia lo santo, la naturaleza inteligible y celestial.

(34) Lo que está en el extremo, lo que llega hasta nosotros, pero no la naturaleza primera y sin mezcla. Vio su espalda, volviéndose a sí mismo en cuanto pudo y abrigado por la roca, el Verbo encarnado. Véase Orat 2, 76; 38, 7 .

(35) 28, 3. Estando más cerca de Dios quizás son esclarecidos según su rango $(28,4)$. 
Como ha dicho un griego, conocer a Dios es difícil, y expresarlo, imposible. A lo que Gregorio agrega: expresarlo es imposible y conocerlo todavía más imposible (36). Captar a Dios sería limitarlo (37). Gregorio muestra que en el A. T. y en el N. T. nadie propiamente ha visto la naturaleza de Dios (38).

La razón nos hace remontar desde las cosas visibles hacia Dios (39). La belleza y el buen orden de lo visible da a conocer a Dios y usa la vista como guía para lo que está por sobre ella (40). El está por encima de todo. Es la naturaleza primera (41), la causa primera (tèn pánton poietikén te kaì sunektikẹnn aitían (42)) de donde las cosas tienen el ser (43). Es una fúsis áleptós te kaì aperíleptos (44). No respecto a su existencia (45) sino a qué es (46). Sabemos que existe, pero "Dios, lo que es su fúsis y su ousía, ningún hombre lo ha descubierto jamás ni lo descubrirá" (47), en esta vida. Justamente "Dios no es aquello que hemos imaginado o representado o la razón (lógos) ha esbozado" (48). Porque, por lo que está en torno a Dios esbozamos lo que le corresponde y componemos una imaginación imprecisa y débil y diversa por sus diversos elementos (49).

(36) 28, 4. Norris (op. cit., 106) se expresa así en su comentario a Or 28: "Within the oration Gregory focuses on the incomprehensibility of God's nature and develops the topic in two ways. First, he argues that Biblical heroes did not know God's nature. Second, he shows that human do not understand fully either their world or themselves and therefore could hardly grasp God's essence".

(37) Una forma de limitación es la catálepsis $(28,10)$. Respecto a este párrafo aclara Norris: "Now he (Gregorio) leads his audience toward the conclusion that the inability to answer the query about spatial location demands that Christians recognize the limitations of human reason".

(38) 28, 18-20.

(39) $28,16$. Véase 28,26

(40) $28,13$.

(41) 28, 3.7.13.14 (texto críticamente no seguro). Según 30, 16, solo para ella (Padre e Hijo) es cognoscible el día y la hora del juicio.

(42) 28, 6. Theoû tà pánta kaì ousiósantos kaì sunéjontos $(28,6)$. Tò poietikòn ...kaì tò kinoûn kaì teroûn tà pepoieména $(28,6)$. "Porque Él es la causa de todo, no tiene causa anterior" $(31,33$; véase 28,13 ). Cf. 28,8 (el que lleva el universo).28s.

(43) 28, 16. Cf. 28, 5.11. Dios les ha dado el movimiento, insertando en todos un lógos; las ordenó y las conserva $(28,16$; véase 31,33$)$. Es el demiurgo del universo que dio orden y delimitó todo $(28,31)$. Véase 28,29 . Las naturalezas incorporales siempre danzan en coro en torno a la causa primera, desde donde reciben el purísimo resplandor, cada una según su naturaleza y rango. Conformados y marcados por la Belleza pueden comunicar a otros los efluvios y trasmisiones de la primera luz. Son servidores de la voluntad divina. Cantan la magnificencia divina y perpetuamente contemplan su gloria eterna. No es para que Dios sea alabado, a cuya plenitud nada se puede agregar (Él es el que concede los bienes a los otros) $(28,31$; véase 28,26$)$. Dios es lo más hermoso (kálliston) entre lo inteligible $(28,6.30 .31 ; 29,4.6 ; 30,2.15 ; 31,29)$. Notemos que Gregorio a menudo destaca lo bello. Dios es el Creador (p. e. 28, 31)

(44) 28, 5. Cf. 28, 11. Katalabeîn dè adunateî $(28,13)$. “Cómo es todo esto y perfectamente cada uno, el uno que por naturaleza es sin composición y sin semejanza (aneíkaston)?” (28, 13). "Nuestro noûs se fatiga por salir de lo corporal y encontrarse directamente con lo incorporal (gumnoîs) mientras mira con su propia debilidad lo que está por sobre su fuerza" $(28,13)$.

(45) Esta nos la enseña la visión y la ley física (fusikòs). Por el raciocinio encontramos al autor (arjegòn) mediante lo visto y ordenado $(28,6)$.

(46) ouj hóti éstin, all' hétis estìn $(28,5)$

(47) 28, 17. Cf. 28, 18.19.21; 31, 8. Abraham "vio a Dios, pero no lo vio como Dios, sino que lo alimentó como hombre" $(28,18)$.

(48) 28,6

(49) 30, 17. El mejor teólogo es el que mejor ha imaginado y reunido en sí mismo la imagen de la verdad o la proyección de su sombra. No es que haya descubierto el todo. Ningún noûs puede comprender en su totalidad la esencia (ousían) de Dios. Cf. 31, 22. 
Después de enumerar largamente, y con admiración, diversos misterios (50) de la naturaleza, partiendo del hombre y culminando en lo incorporal (ángeles, etc., primeras naturalezas después de Dios) (51), concluye la Orat 28 que lo de la naturaleza de las cosas segundas es superior (kreítton) a nuestro noûs (52). ¿Cómo lo será lo de la naturaleza primera y única, de la que duda decir que está por sobre todo? La razón de dudar, según nota de Gallay, es porque esta jerarquía no condice con su absoluta trascendencia. Luego, si no podemos conocer la fúsis de Dios, es falsa la definición de Él que dan los adversarios (Eunomio), diciendo que es el agénneton (53).

Lo divino es sin límite, infinito (aóriston), sin forma (asjemátiston), impalpable, invisible. No hay división (diástasis) ni composición ni cuerpo en Dios (54). Dios penetra todo y llena todo (55). La envidia está lejos de la naturaleza divina, exenta de pasiones, única buena y soberana (56). Dios es la hermosura suprema (57). Pero decir que sea incorporal no hace comprender su esencia (ousías), como tampoco el que sea ingénito, sin principio, inmutable, incorruptible, y cuanto se dice respecto a Dios. Esto no nos dice lo que es Dios desde el punto de vista de la fúsis e hupóstasis (58). Porque después de decir lo que no es la naturaleza del 'que es', habría que decir también lo que es (59). Pertenece solo a Dios el ser digno de veneración y estar por encima de toda substancia y naturaleza: esto es como si fuera (hoioneì) la naturaleza de la divinidad (60). Varios nombres se aplican a Dios. Pero lo divino no puede ser designado por ningún nombre (61). El más propio es "el que es" (Ex 3, 14) (62), porque es un absoluto sin relación a nosotros, contrariamente al

(50) Dios es el que conoce (oîden) (28, 31). Cf. 28, 30. Es el que ilumina el noûn (28, 30). En estos misterios de la naturaleza obra Dios, como en la purificación por el agua en tiempos de Noé $(28,28)$.

(51) 28, 22-31.

(52) Cf. también 28, 28; 31, 8. Véase 29, 8.

(53) Véase 29, 10.11.12; 31, 23.

(54) 28, 7. En los números siguientes continúa hablando del incorporal. Es la naturaleza indisoluble (30, 17; cf. 28, 7). Dirá Norris (op cit., 40s): "Such positions echo those taken by a number of Greek philosophers, particularly the developing Platonic tradition. Yet Gregory sees them as related to his Christian tradition. No inspired teacher has ever taught that God is corporeal (28, 9). An each of the concepts listed above, both the nouns stated positively and the adjectives stated negatively as alpha-privatives, is in his view a correct inference from God's incorporeality. Although Nazianzen insists that God's nature is incomprehensible, he is willing to make general statesments about God that were a part of his Christian and Greek heritage. ...He can say positive things about God's economy that indicate certain aspects of God himself. ...God's nature, for him, is not so incomprehensible that God's existence, goodness, power, providential ordering and his lack of composition, conflict, disorder and disolution are unknown".

(55) 28,8 .

(56) 28, 11. La existencia de las creaturas se debe a su suma bondad. No obra por su propia honra y gloria el que está lleno de ella (cf. también 28, 31). Dios no miente $(29,11)$ ni olvida su alianza $(28,28)$.

(57) 31,15 . Cf. 28,30 .

(58) La inmortalidad, la inocencia (ákakon) y la inmutabilidad tampoco son la esencia de Dios, porque son comunes con otros $(29,10 \mathrm{~s})$.

(59) 28, 9. Véase 29, 11.

(60) 29, 14. Normalmente traduciremos ousía por substancia. Cf. 28, 5.7.16.31

(61) 30, 17. Los más sabios de los antiguos hebreos no soportaban que con las mismas letras se escribiera también algo inferior a Dios, porque pensaban que la divinidad no debía tener nada común con lo nuestro.

(62) Véase 28, 9; 31, 23. En 30, 17 es llamado tò pân. Cf. p. e. Orat 38, 7: hoîón ti pélagos ousías ápeiron kaì aóriston. 
nombre theós (63), Kúrios (64). Dice Gregorio: “Así de Dios hay una sola substancia y naturaleza y designación, aunque los nombres se distingan con algunas diversas concepciones (epinoíais). Lo que se diga propiamente de Dios, eso es Dios; y lo que Dios sea por naturaleza, eso lo nombra verdaderamente, supuesto que no en los nombres sino en las cosas (prágmasin) está para nosotros la verdad" (65).

\section{1) TRINIDAD (66) Y MONARQUÍA}

Sus cinco discursos son una defensa de la Trinidad ante los ataques arrianos, sobre todo de los eunomianos (67). Hecha la introducción de los dos primeros donde trata principalmente del modo piadoso de abordar el tema (Or 27) y de la incognoscibilidad de Dios (Or 28) contra el intento de Eunomio de conocerlo y de definirlo por el agénneton (68), pasa a tratar detenidamente del Hijo ( $O r 29$ y 30) y del Espíritu Santo (Or 31), en un contexto trinitario. Nosotros comenzaremos por englo-

(63) Ambos son más bien como nombres de la substancia (ousías). Véase también 29, 12.

(64) 30, 18. Tò òn (ho ón) es verdaderamente propio de Dios, sin que ningún otro lo limite o mutile.

(65) 29, 13. Comenta Norris: "reality is prior and language follows. ...The later Arians depend upon an opposite view, that names determine essence". Véase Orat 43, 68. De las otras denominaciones de Dios, unas se refieren a su poder y otras a la economía, ya sea sobre lo supracorporal o sobre lo corporal (la Encarnación, según Norris). A la potencia se refieren: Omnipotente, Rey, de la gloria, de los siglos o de las potencias, del amado, de los que reinan, Señor, Sabaot (de los ejércitos), de los que ejercen el señorío. A la economía se refieren: Dios, de salvación, de las venganzas, de la paz, de la justicia, de Abraham e Isaac y Jacob y de todo el Israel espiritual y que ve a Dios $(30,19)$

Hay cosas que no existen, pero que se las dice, p. e. Dios duerme, etc. "Nombramos, como podemos, las cosas de Dios a partir de lo nuestro" $(31,22)$. Así lo imaginamos. Diversas potencias de Dios o actividades nos las figuramos con diversas imágenes corporales. En 28, 13 se había preguntado sobre espíritu (pneûma), fuego, luz, amor, sabiduría, justicia, noûs, lógos, como denominaciones de la naturaleza primera (cf. 28, 31).

(66) Norris (op. cit., 41-44: "An equal lack of interest in using philosophical argument to undergird his claim marks his use of Trinitarian formulae. ...When Nazianzen attempts to define more closely the relationships within the Trinity he uses at least three methods: reference to heretical errors, discussion of analogues and emphasis upon the economy of salvation. ...There is no philosophical justification for his Trinitarian views within these orations. Philosophical concepts are employed, but in almost every case the only clarification is provided in the use either of several terms in the same paragraph, or of contrasting words in a phrase or a clause. The terms are apparently used analogically rather than foundationally. ...Because Nazianzen usually avoids philosophical justification for his positions, it may not be appropiate to view him as the creator of a new Christian philosophy, a claim made for Basil and Nyssa. The Theologian attacks Eunomian paideia to point out its deficiency in dialectics and rhetoric. He employs philosophical terms in order to make Trinitarian thought plausible, but his insistence on the incomprehensibility of God's nature, his analogical use of philosophical terms, his reliance on the traditional Christian confessions and his Scriptural exegesis demand that he should be viewed no as a philosophical theologian or an apologist in any modern sense of those terms".

(67) Aunque navega entre sabelianos y arrianos (eunomianos) (cf. p. e. 31, 9.30; Orat 20, 5s: donde busca la mesótéta evitando los dos extremos; véase Orat 2, 36-38; 21, 13; 33, 16; 39, 11; 42, 16, etc.), sus principales adversarios son estos últimos. Según Orat 25, 16, ni tres principios (arjás) (véase 31,30 ) para no ser helénico y politeísta, ni un principio a la manera judaica, estrecha, envidiosa, impotente o en que la divinidad se reabsorbe a sí misma... (véase, p. e. Orat 20, 6).

(68) Este término no es bíblico, pero en 31, 23, Gregorio pone textos bíblicos que lo implicarían: no tiene causa anterior. 
bar lo más posible su expresión trinitaria con algunos de los problemas que conlleva, para centrarnos después en el Hijo y en el Espíritu.

En estos cinco discursos utiliza el vocablo triás 13 veces (69). En las Or 29-31

habla a menudo de los tres por sus nombres o propiedades, o de dos o uno de ellos (70). Llama la atención que en 8 de los textos en que utiliza triás, la Trinidad va combinada o identificada con la afirmación de la única divinidad o naturaleza o substancia divina. Esto nos confirma lo del momento teológico de Gregorio que veíamos en la Introducción (71). Encontramos el mismo equilibrio entre Trinidad y unidad en la introducción al primer discurso propiamente trinitario (72) y en la

(69) Según 28, 3, contrapuesto a nuestro no conocer la naturaleza primera y sin mezcla (Dios), esta es conocida para sí misma, es decir, para la Trinidad. Por consiguiente, cuando se trata de "autoconocimiento", la naturaleza primera es la Trinidad.

Según 28, 31, si ha alabado dignamente, es la gracia de la Trinidad y de la única divinidad en los tres. Cerrando, pues, este discurso sobre la incognoscibilidad de la divinidad en que los diversos incorporales contemplan la gloria de Dios y cantan su grandeza, la alabanza de Gregorio es una gracia de la Trinidad que tiene, o es, una única divinidad.

En 29, 2, diferenciando la monarquía no limitada a un prósopon, de la anarquía y de la poliarquía, dice que ella está constituida de igual dignidad de naturaleza y acuerdo del querer e identidad del movimiento, y convergencia a la unidad de los que vienen de ella, de manera que, aunque haya diferencia por el número, no se divida en la substancia (ousía ${ }_{\mathbf{i}}$ ). "Por esto, desde el comienzo la mónada, en movimiento (kinetheîsa) hacia la díada se ha detenido en la tríada [triádos, que traducimos en los otros sitios por Trinidad]. Y esto es para nosotros el Padre y el Hijo y el Espíritu Santo".

Al final de este discurso, en 29, 21, declara que, al menos él, quiere salvar la Trinidad para sí mismo y ser salvado por la Trinidad.

En 31, 3, confiado en la divinidad del Espíritu, aplica las mismas voces a la Trinidad. Así aplica Jn 1, 9 al Padre, y al Hijo, y al Paráclito. "Era y era y era, pero era uno (hén). Luz, luz y luz, pero una sola luz y un solo Dios". Muestra, pues, la igualdad de los tres, manteniendo que Dios es uno. Y concluye, a propósito del Sal 35, 10 (numeración de los LXX): "de la luz -el Padre-, captamos la luz -el Hijo-, en la luz -el Espíritu-, teología breve y simple de la Trinidad".

En 31, 5 hablando del Espíritu, dice que ya antes discutió sobre la Trinidad.

En 31, 10, en la discusión con los adversarios sobre la diferencia entre lo propio del Hijo y del Espíritu, dice: "dame tú también otro Dios y la naturaleza de Dios, y yo te daré la misma Trinidad con los mismos nombres y realidades. Y pasa a buscar una comparación.

En 31, 12, después de declarar que ir contra el Hijo es deshonrar al Padre, e ir contra el Espíritu es deshonrar al Hijo, pide que el otro no mezcle nada de la Trinidad consigo mismo para que no se separe de la Trinidad. "No amputes nada a esta naturaleza única e igualmente venerable. Porque si sacas algo de los tres, serás destructor de todo, más bien tú quedarás fuera del todo". Por tanto, quitar algo a la Trinidad, que es un todo, es quitar algo a la única naturaleza (véase también, p. e., Orat 6,11). Esto muestra claramente la identificación real de la única naturaleza con la Trinidad. Véase, p. e., 31, 9 (Hèn tà tría theótenti, kaì tò hèn tría taîs idiótessin); Orat 39, 11 (Hèn gàr en trisìn he theótês, kaì tà tría hén).12.

En 31, 15, habla de los ángeles y de toda naturaleza superior que venga después de la Trinidad, los que están en la cercanía de la belleza suma. La Trinidad, por tanto, es la belleza suma, que suponemos única.

Finalmente, según 31 , 26, la luz de la Trinidad resplandecerá para los más brillantes (lamprotérois) después de ascensiones progresivas.

(70) También aparecen a menudo theótes y theós en contexto trinitario.

(71) Según 28, 31, si ha dignamente alabado, es gracia de la Trinidad y de la única divinidad en los tres. Cf. 31, 3.14.28. Véase p. e. Orat 25, 17.

(72) "Pongamos en la cabeza de este discurso al Padre y al Hijo y al Espíritu Santo, sobre los que es el discurso, de forma que el primero sea benevolente (eudokeîn), el segundo coopere (sunergeîn) (véase 30,5) y el tercero inspire (empneîn), o más bien que se haga una única iluminación de la única divinidad, unitariamente distinta y distintamente reunida (henikôs diairouménen kaì sunaptoménen diairétos), lo que es paradójico" $(28,1)$. 
conclusión del último (73), etc. Por otra parte, a los tres una sola vez les aplica hupostáseis (74) (salvo el texto de 28,9$)(75)$ y nunca directamente prósopa (76). Esto nos indica que la distinción no es tanto puesta en un problema de vocabulario como 3 hupóstasis o prósopon, sino en las propiedades (idiótess) (77). El texto de 31, 9 nos resume esto. Según él, nada le falta al Espíritu, nada le falta al Hijo. La filiación no es una carencia. Tampoco se trata de una inferioridad (huféseoss) según la substancia. "El no ser engendrado, el ser engendrado y el proceder (tò ekporeúesthai) (78) designan al Padre, y al Hijo, y al Espíritu Santo, del que aquí se habla,

(73) “Adorar al Padre y al Hijo y al Espíritu Santo, la única divinidad y poder (dúnamin), porque 'a El toda gloria, honor, poder (krátos), por los siglos de los siglos' [Ap 1, 6; 5, 13]. Amén” (31, 33).

(74) 31, 9. En la cita de Hb 1, 3 en 29, 17, hupóstasis se entiende en el sentido de $\mathrm{Hb}$

El peligro que ve en comparar la Trinidad con el sol, el rayo y la luz es que substancialicemos (ousiósomen) al Padre y no hipostasiemos (hupostésomen) a los otros haciéndolos fuerzas que existen (enuparjoúsas) en Dios pero no son hipóstasis (hufestósas) $(31,32)$. Porque el rayo y la luz son solo emanaciones solares, cualidades substanciales. Según 31, 11, es reconocido que se puede admitir que tà diafóros hupostánta tê̂s autês eînai ousías. En 31 , 6, tôn kath'heautò hufestekóton es lo que llaman ousía y se contrapone a tôn en hetéro $\underline{o}_{i}$ theorouménon (tò sumbebekós).

(75) Según nota de Gallay, hupóstasis sería en este texto un sinónimo de fúsis. Pero nosotros creemos que más bien insinúa de paso que agénneton (ánarjon en sentido más propio) no es 'propiedad' de la ousía (perì theoû), como asómaton, analloíoton, áftharton, sino del Padre (perì theón; cf. el perì ousían de 29,12 ). En ese sentido diría que hay cosas que le corresponden katà fúsin y otras katà hupóstasin). Gregorio no podía dejar pasar como propiedad de la esencia de Dios el agénneton, porque eso era darle la razón a Eunomio. Pero lo hace de paso porque aquí no está tratando de la Trinidad sino de que el conocimiento de Dios, de su naturaleza, es negativo (se dice lo que no es) y no positivo. Según Norris (op. cit., 194), "Hupóstasis, 'person', and fúsis, 'nature' have long histories and can be traced in abundant secondary literature, but they do not habe a strong context in Nazianzen's corpus". Cf. S. Zañartu, Algunos desafíos del misterio del Dios cristiano a las categorías del pensar filosófico en la antigüedad, y viceversa. Lógos e hupóstasis (persona) hasta fines del siglo IV, Teología y vida 33(1992)35-58.

(76) Véase 29, 2. Los sabelianos combinan (sunápsai) respecto a la persona y los arrianos separan respecto a las naturalezas $(31,30)$. Véase p. e. Orat 23,$8 ; 34,8 ; 39,11$. En 30, 1 habla del prosopopoieîn de la Escritura.

(77) Según Orat 20, 6, por ejemplo: "Es necesario sostener un solo Dios y confesar tres hupostáseis o tres prósopa, cada una con su propiedad". Véase Orat 21, 35; 39, 11; 42, 16. Respecto a las fórmulas pueden consultarse las sugerencias de A. de Halleux, 'Hypostase' et 'Personne' dans la formation du dogme trinitaire (ca 375-381) (RHE 79(1984) 313-369; 625-670), pp. 642-646. Dice este autor (Ib., 667): "L'une hypostase des vieux-nicéens désignait la substance, la nature ou l'esence de Dieu tout entière, risquant par là de reléguer les personnes dans le domaine de la manifestation économique, tandis que les néo-nicéens, visant la réalité ontologique de Dieu par les trois hypostases aussi bien que par l'ousie, allaient désormais devoir rendre compte de la distinction et du rapport de ces deux concepts en faisant appel, entre autres, aux categories logiques aristotélico-stoïciennes du commun et du particulier ou de la relation, ainsi qu'à la métaphysique moyen et néo-platonicienne de l'union inconfuse d'êtres spirituels par leur totale interpénétration"

(78) Cf. también 29, 2.3; 31, 8. En 29, 2 el Espíritu es llamado próblema en relación al Padre prosboleús, quien respecto al génnema es llamado gennétor. En 30, 19, los presenta así: "El nombre propio del sin principio, es Padre; del engendrado de modo sin principio (anárjos, equivale aquí a eternamente), Hijo; del que de modo no engendrado (agennétoss) prosigue (proelthóntos) o procede (pröióntos) hacia, el Espíritu Santo.” El Hijo no procede (ouk ekpeporeútai), sino que ha sido engendrado $(29,3)$. Según Orat 39, 12, el Espíritu procede (proïòn) del Padre no huiikôs ni gennetô̂s. Según Orat 25, 16, ékpempsis es lo propio del Espíritu. Habla también del próodos del Espíritu en Orat 2, 38; 20, 10.11; 23, 7.11; 25, 16.17; 42, 18. Según J. Rousse, col 944, en Grégoire de Nazianze (DSp VI, col 932-971), “C'est Grégoire qui introduit le concept de procession (ekpóreusis) afin de préciser la qualité de la relation propre de cette Personne de la Trinité que se situe entre (méson) l'Engendré et l'Inengendré $(31,8)$ "' 
para que sea salvada la no confusión (tò asúgjuton) de las tres hipóstasis en la única naturaleza y dignidad de la divinidad. Porque ni el Hijo es el Padre, pues hay un solo Padre, sino lo que es el Padre (79), ni el Espíritu es el Hijo por (venir) de Dios, pues hay un solo Unigénito, sino lo que es el Hijo (80). Los tres son uno en la divinidad y lo uno es tres en las propiedades" (81). Siguiendo con lo de la propiedad (82), en 29, 12 dice que, si buscamos cuál es la substancia de Dios, dejemos intacta la propiedad, que en este caso es 'inengendrado' (el Padre) (83). Porque 'inengendrado' no es la substancia, dado que la diferencia entre ingénito y engendrado solo está en torno a la substancia (perì ousían) (84).

Más claro respecto a este 'en torno a la substancia', es el texto de 29, 16 : "El Padre no es un nombre de substancia ni de acción (energeías) (85); es un nombre de relación (sjéseos) (86) y de cómo se tiene el Padre respecto (prós) al Hijo o el Hijo respecto al Padre. Así como estas apelaciones dan a conocer entre nosotros la procedencia de nacimiento y el parentesco, así también allí significan la identidad de naturaleza (homofuïan) del engendrado respecto al que lo ha engendrado". En 31, 7 dirá que el Hijo es Hijo según una relación de tipo más elevado (87), porque viene de Dios y a la vez es consubstancial. Según 31, 9, aunque al Espíritu no le falte nada en cuanto es Dios, sin embargo no es hijo por la diferencia de manifestación o de

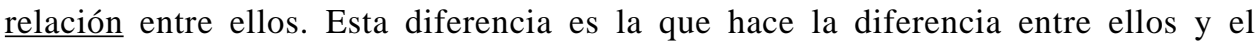

(79) En 29, 10, etc. hablará de tautòn eînai... katà tèn fúsin. Véase 29, 2. Según Ep 101, 21, el juego entre masculinos y neutros en la Trinidad es contrario a en cristología.

(80) "Pero si todo lo que tiene el Padre es del Hijo, salvo lo de ingénito, si todo lo que tiene el Hijo es también del Espíritu, salvo la filiación y cuanto se dice corporalmente de Él, a causa del hombre que soy y de mi salvación -a fin de que tomando lo mío me regale lo de Él mediante esa nueva mezcla (anakráseos) - cesad, bien que tardíamente, de desvariar" (Orat 34, 10). Cf. p. e. Orat 41, 9.

(81) 31,9 .

(82) En 31, 31 diría que la diferencia (témnesthai) entre ellos se daría por las tres propiedades, Según 31, 28, Gregorio quiere venerar a Dios el Padre, a Dios el Hijo, a Dios el Espíritu Santo, tres propiedades, una divinidad, no dividida en la gloria, ni en la honra ni en la substancia ni en la soberanía (basileía $\mathbf{a}_{\mathbf{i}}$ ).

En 31, 29 afirma que el Espíritu, siendo Dios, puede recibir los diversos nombres, menos el de inengendrado (agennesías) y engendrado (gennéseos). "Porque era necesario que las propiedades permanezcan para el Padre y para el Hijo, para que no haya confusión en la divinidad".

En 30, 19, después de tratar de nombres comunes de la divinidad, habla del nombre propio de cada uno, como vimos más arriba.

(83) Ahí no está lo tautón.

(84) Para explicar esto ha dicho en 29, 10, que lo sabio y lo no sabio no son lo mismo, pero conciernen a lo mismo (perì tautón), al hombre: no divide la substancia, sino que se divide perì... ousían. "Todo cuanto es el Padre, es del Hijo, salvo el ser ingénito. Todo cuanto es el Hijo, es del Espíritu, salvo el ser engendrado. Todo esto no divide la substancia sino que se divide perì ousían" (Orat 41, 9). Según 28, 9, incorporal, inengendrado, sin principio, inmutable, incorruptible serían de las cosas que se dicen ser respecto a Dios (perì theoû) o perì theón. Según 31,6 , si el Espíritu no es un accidente, ni en torno a la substancia, sería una substancia. Dice en Orat 42 , 15: "Lo sin principio ni lo ingénito es la naturaleza del sin principio, porque ninguna naturaleza se define (hó ti) por aquello que no es sino por aquello que es. ...Porque estas cosas están perì fúsin, pero no son la fúsis".

(85) Pero aunque fuera nombre de substancia o de acción, produciría un consubstancial.

(86) Véase Basilio, C. Eunom I, 5, 68s; De Spiritu Sancto, VI, 14, 8; PseudoAtanasio, Dialogus de Sancta Trinitate 1, 25; Gregorio de Nisa, Orat cath magna, 1, 10; Anfiloquio de Iconio, Fragm, 15, PG 39, 112CD.

(87) katá tina sjésin hupselotéran. 
nombre (diverso). En resumen, las propiedades que diferencian las hipóstasis, Gregorio las explica, no como substancias sino como relaciones.

Pero frente a ellas, a los tres, está la consideración de la unidad, que siempre acompaña a Gregorio en sus equilibradas expresiones. Contra los adversarios defiende, en los discursos 29 a 31, que el Hijo es Dios y el Espíritu también. Más adelante nos referiremos a algunos de sus argumentos más en detalle. Basta aquí con llamarlos consubstancial (88), lo que expresa la unidad. Hay una sola divinidad en los tres (89), una sola divinidad y tres propiedades (90), una sola divinidad y poder (91), una sola luz y un solo Dios (92), una sola naturaleza (fúsis) (93), etc. "Cada uno de ellos no tiene menos el ser uno con (prós) el que está con él (sugkeímenon) que (prós) consigo mismo, por la identidad de la substancia y del poder" (94). En esta línea de la unidad, habla nuestro autor de la monarquía.

En 29, 2 (95), la monarquía se opone a la poliarquía y a la anarquía entre los dioses, que tanto entretuvieron a los hijos de los griegos (96). Nosotros, dice Gregorio, honramos la monarquía (no monopersonal) sino la que está constituida de igual dignidad de naturaleza y acuerdo del querer e identidad del movimiento, y retorno (súnneusis) a la unidad de los que vienen de ella, de manera que aunque haya diferencia por el número no se divida en la substancia (ousía $\mathbf{i}_{\mathbf{i}}$ ). "Por esto, desde el comienzo la mónada (97), en movimiento (kinetheîsa) hacia la díada se detiene en la tríada (98). Y esto es para nosotros el Padre y el Hijo y el Espíritu Santo". La monarquía es, en conclusión, la unidad de los tres, que termina expresándose en la no división de la substancia. Pero también habla Gregorio de un como "movimiento', que es lo que está entre el engendrante y productor (proboleús) y el engendrado y el producido (próblema). La unidad, pues, tiene su consistencia de origen en cierto "movimiento" (99) de la mónada a la tríada, con un retorno. La mónada no es la divinidad común sino el Padre.

(88) 29, 16; 30, 20; 31, 7.10.11. 29. En 31, 17-20 hay una larga discusión sobre el contar los consubstanciales.

(89) 28, 31. "La adoración de uno es adoración de los tres, porque en los tres es el mismo rango de dignidad y de divinidad" $(31,12)$. Véase, p. e. Orat 33, 16.

(90) 31, 28. Divinidad no dividida en gloria, honra, substancia, soberanía. Véase, p. e. Orat 20, 5; 33, 16: "una sola naturaleza en tres propiedades inteligentes, perfectas, subsistentes por sí mismas (kath' heautàs hufestósais), distintas (diairetaîs) por el número, y no distintas por la divinidad"

(91) $31,33$.

(92) 31,3

(93) 31, 9.12. Fúsis sin composición $(31,32)$ ni mezcla $(28,3)$.

(94) 31,16 .

(95) Tres veces aparece la palabra en este texto.

(96) Incidentalmente muestra Gregorio su aprecio por la unidad, cuando tratando en 30, 20 de las designaciones del Hijo, dice que se lo llama "Verdad, en cuanto uno y no muchos por naturaleza. Porque lo verdadero es uno y la mentira es múltiple (polusjidés). En 28, 7 dice, defendiendo que lo divino no es compuesto, que la composición lleva a la disolución. Cf. 29, 2. Véase 30, 6.

(97) En 31, 18 se usa 'mónada' para unidades diferentes, aunque estén unidas por la substancia (sean consubstanciales)

(98) "La mónada se pone en movimiento en virtud de su riqueza, se sobrepasa la díada..., se limita en la tríada por la perfección, que es la primera en sobrepasar la composición de la díada, de manera que la divinidad no permanezca estrecha ni se esparza al infinito" (Orat. 23, 8). Lo primero sería judío; lo segundo helénico y politeísta. Según Orat 38, 8, Dios es Padre, Hijo y Espíritu, para no judaizar mediante la monarquía, y para no helenizar mediante la sobreabundancia (pueblo de dioses).

(99) Véase también, p. e. Orat 20, 7; 38, 9. 
El segundo texto sobre la monarquía es el de 31, 14 (100). En él la monarquía, junto con la divinidad y causa primera aparece en el polo de la unidad, contraponiéndose al polo de los tres que adoramos, en los que está la divinidad, y a los que vienen eternamente de la causa primera y son iguales en dignidad (101). Interpreto aquí la causa primera como el Padre, contra el comentario respectivo de Norris, porque vienen de él (ek... ekeîthen ónta) (102), porque en 29, 15, por ejemplo, se refiere al Padre como aitía del Hijo y en ese sentido es más grande que este (y no por naturaleza), y por paralelismo con el texto que de 29, 2, que vimos antes, en que, siendo el Padre y el Hijo la díada (diferenciada de la tríada trinitaria), la mónada es ciertamente el Padre de donde parte ese cierto movimiento: el Padre es el que engendra y produce, como dice ese texto a continuación. Por lo demás en 29, 2 también rechaza que se trate de un desbordamiento de bondad, porque sería una generación involuntaria (103). Finalmente, el tercer texto es el de 31, 17, donde Gregorio dice al adversario que está negando la consubstancialidad de los tres, que al no darse el trabajo de defender la monarquía, niega la divinidad. Esto nos vuelve a recordar que monarquía es la unidad de los tres (104). Monarquía es, por tanto, para Gregorio, una palabra que indica tanto la unidad como la distinción (105).

Aunque monarquía dice la unidad de los tres, al interior de ella hay una especie de 'movimiento', según dos (106) de los tres textos vistos. Según ellos, el Hijo y el

(100) "Cuando, pues, por una parte miramos a la divinidad y a la causa primera y a la monarquía, se nos aparece lo uno, pero cuando miramos hacia aquellos en los que está la divinidad y a los que vienen de la primera causa atemporalmente y con igual gloria, adoramos a tres".

(101) Esto se refuerza por lo que antes había dicho en este mismo párrafo: "un solo Dios, porque una sola divinidad. Y hacia la unidad (pròs hén) se vuelve (tèn anaforàn éjei) lo que viene de él, aunque sea creído que son tres. Porque el uno no es más Dios y el otro menos Dios; ni el uno es primero y el otro posterior. Ni se escinden en la voluntad, ni se dividen en el poder..., sino que la divinidad, si es necesario hablar brevemente, es sin división en los distintos (améristos en memerisménois)". Es, pues, una afirmación a la vez de los tres (la diferencia) y de la unidad, que va seguida de la comparación de los tres soles que se compenetran, siendo única la fusión de la luz. Y finalmente sigue lo de la monarquía que estamos analizando. Como que los tres párrafos tuvieran un ritmo parecido. A la luz de esto creemos que el uno, del que provienen y al que retornan, según el texto puesto al comienzo de esta nota, es el Padre, igual que en el texto de la monarquía de $29,2$.

(102) Recordemos que Padre e Hijo son nombres de relación (29, 16). Puede verse J. P. Egan, Primal Cause and Trinitarian Perichoresis in Gregory Nazianzen's Oration 31, 14, en Studia Patristica 27, pp. 21-28.

(103) Respecto a que Dios crea y engendra queriendo, cf. 29, 6. En 30, 3 hablará de he apórroia toû prótou kaloû, que llega secundariamente a los hombres buenos.

(104) Véase también, por ejemplo, Orat 40, 41.

(105) Según Orat 25, 15, por la monarquía se nombra al Hijo 'Señor' junto con el Padre; en cambio, se lo nombra 'Dios', por la naturaleza, cuando se lo considera en sí. Este texto insinúa que la monarquía, unidad con el Padre, estaría en relación a nosotros, junto con el señorío. Según Orat 40, 41, cada uno de los tres es Dios, contemplado en sí mismo (guardada para cada uno su propiedad); y los tres son Dios si se los contempla en conjunto. Lo primero por la consubstancialidad; lo segundo por la monarquía. Véase Orat 25, 18, etc.

(106) Se incluye además el comienzo del 31, 14. Cf. Orat 20, 7. Afirma Bergmann (op. cit., 161-163): "Für Plotin ging die Vielfalt der Wirklichkeit aus dem Wesen hervor, dessen höchste Eigenschaft die Einheit war. Gegen diese Auffassung von der Einheit setzt Gregor seine These von der Qualität der Bewegung als höchste Vollendung des göttlichen Wesen. Gerade durch die vollkommene Übereinstimmung von Willen und Bewegung der drei Hypostasen zeichnet sich die Einheit der göttlichen Natur aus. Die Vollkommenheit dieser göttlichen Einheit zeigt sich jedoch nicht in der Einheit der Person, sondern gerade in der vollkommenen Bewegung, die die Einheit 
Espíritu provienen del Padre y se vuelven hacia Él. Aunque no hay mayor ni menor, ni anterior ni posterior, el Padre es el que engendra y produce y los otros son el engendrado y el producido. Esto lo hace el Padre impasiblemente, atemporalmente, incorporalmente (107), Él que es la mónada, la primera causa. El Padre es, pues, la aitía del Hijo. Así, según 29, 3, el Hijo y el Espíritu no son sin principio respecto a la causa, el Padre (108). Así, según 29, 15, el Padre es mayor que el Hijo por la causa (t $\underline{\hat{o}}_{\mathbf{i}}$ aitío $\underline{\mathbf{i}}_{\mathbf{i}}$ meízonn) y no por naturaleza. Dicho de otro modo, la naturaleza de la causa (toû aitíou) no es mayor (109). En 30, 7 confirma lo mismo (110). En 31, 14 se nos dice, contrastando con mirar a los tres, que cuando miramos a la divinidad y a la causa primera y a la monarquía, se nos aparece lo uno. ¿Esa causa primera es aquí Dios, como cuando se habla en relación a la creación (111), o es el Padre

konstituiert. Um aber die Übereinstimmung der Gemeinschaft der drei Hypostasen als konstituierend aussagen zu können, ohne Vorauszusetzen, dass diese Gemeinschaft der Einheit von je drei verschiedenen Punkten her ihre Ausgangspunkte nimmt, entfaltet Gregor den Gedanken der Bewegung als eine Eigenschaft im Wesen der Einheit Gottes. Die Zeugung des Sohnes durch den Vater und der Ausgang des Geistes aus dem Vater sind Ausdruck ein und derselben Bewegung innerhalb der göttlichen Natur. Bewegung zeichnet so gerade die göttliche Einheit als Einheit aus. Das 'aus diesem Grunde' bezieht sich so auf die unerschaffene eine Natur Gottes, deren Vollkommenheit gerade in der innertrinitarischen Bewegung erscheint, die die Einherrschaft konstituiert. ...Bewegung und Zeit sind nicht mehr notwendig untrennbar verbunden. Gregor scheidet nun eine Bewegung in der Zeit von der Bewegung Gottes, aus welcher die Zeit erst quillt. Die unerschaffene Bewegung Gottes unterscheide sich von der erschaffenen dadurch, dass die göttliche Bewegung sich von Ursprung über den Durchgang hin wieder zum Ursprung bewege und somit die vollkommene Kreisbahn beschrieb. Die Bewegung des Schöpfers zeichne im Gegensatz zu der der Schöpfung die Synneusis aus, die Fähigkeit zur Rückführung des Ziels auf den Anfang und vollkommener Verbindung der Bewegungspunkte miteinander. Damit ist die aristotelische Ontologie überwunden, deren grundlegender Gegensatz zwischen Bewegung und Ruhe bestand. Dreifaltige, zeitunabhängige, vollkommene Bewegung stellt nun in der Ontologie Gregors den Gegensatz zur Bewegung der erschaffenen Natur dar. Im Vergleich zur Schöpfung ist Gottes Sein 'unbeweglich und ewig' (Orat 7, 19). ...Während Origenes dem monistischen Gottesbild stärker verhaftet blieb, und die trinitarischen Aussagen subordinatorisch gestaltete, gelingt es nun Gregor mit Hilfe der Vorstellung von einer vollkommenen gemeinsamen Bewegung innerhalb der Trinität, die Gleichheit der drei göttlichen Hypostasen auszusagen. Gregors innertrinitarischen Bewegungsgedanken können wir als eine relationale Bewegung verstehen. ...Die innertrinitarische Bewegung ist eine den drei verschiedenen Hypostasen gemeinsame Bewegung.

(107) 29,2

(108) Cf. p. e., Orat 20, 7.10. Según Or 20, 6, el Padre es la causa de la divinidad que se contempla en el Hijo y en el Espíritu. Ser arjé es la dignidad del Padre. Según Orat 23, 6, el Padre es el principio de la divinidad. El Padre es anaítios (cf. 29, 11; 30, 7).

(109) Los adversarios agregan que es causa por la naturaleza. Véase Orat 40, 43.

(110) 'Mayor' concierne la causa; 'igual', la naturaleza. Y alguien podrá preguntarse si es menor venir de una tal causa a ser sin causa (anaitíou), como el Padre añadiríamos nosotros. Por venir del sin principio (anárjou) participaría de la gloria del sin principio. Porque responder a la objeción diciendo que el Padre es mayor que Cristo en cuanto hombre, es verdad, pero no es decir gran cosa, dado que es obvio. Según 30, 11, entre el Padre y el Hijo "nada es propio, porque todo es común. Puesto que el mismo ser es común, y de igual dignidad (homótimon), pero desde el Padre al Hijo".

(111) Aitía es dicho de Dios en relación a la creación en 28, 6.13.29; 31, 33. Igualmente en 28,31 se habla del prôton aítion. Solo la divinidad es anaítios (30, 2; cf. 31, 23). En 29, 10 ánarjon es contrapuesto a creado.

En 29, 19, causa se aplica respecto a Cristo, en contraposición al Hijo, que existía antes. Dice así: "En el principio era sin causa (anaitíos). Porque, ¿cuál es la causa de Dios? Pero después llega a ser por una causa. Esta era el que tú insolente fueras salvado". Si al Logos se le aplica adverbialmente el sin causa, es por su divinidad. Igualmente en 30, 11 se aplica el respectivo adverbio al existir del Hijo ajrónos viniendo del Padre, por (diá) el que vive, que se contrapon- 
(112)? Creo que también es el Padre, porque aquí no habla en relación a la creación sino que trata de la Trinidad en sí. Esto se confirma, porque a continuación, según la interpretación antes dada, vuelve a hablar de la causa primera de la que provienen atemporalmente y con igual gloria dos y así forman los tres de la Trinidad que adoramos. Si está junto con la monarquía en la primera parte es porque señala la unidad, aunque no de la misma manera que la divinidad. La unidad, por tanto, estaría puesta aquí de una manera especial en el Padre y esta insistencia en el Padre (113) redundaría en la concepción de la 'monarquía'. El Padre, que es el inengendrado, el sin principio (114), no viene de nadie (medamóthen) (115). Pero son pocos los textos que, como hemos visto en este párrafo, destacan así al Padre. Porque el momento teológico de Gregorio no es este (116) sino el de la igualdad en la consubstancialidad, es el momento de la Trinidad resplandeciente y de la única divinidad. Este es el equilibrio de los dos polos que, contra sabelianos y arrianos, Gregorio busca siempre.

\section{2) LA DIVINIDAD DEL HIJO (117)}

Habiendo considerado brevemente cómo Gregorio dice la Trinidad y a la vez la unidad en Dios, descendamos ahora a probar, siguiendo a nuestro autor, la divinidad

dría a recibir el vivir y ser sostenido por el Padre, como hombre. Aun podríamos compararlo con la aplicación al Hijo del adverbio anárjos en 30, 19, siendo el Padre el ánarjos: "Pero (nombre) propio del anárjou, Padre; del engendrado anárjos, Hijo."

Pero más claro parece el texto de 30, 2, refiéndose a 'Él me creó' de Pr 8, 22 y 'Él me engendró' de $\operatorname{Pr} 8,25$, comenta respecto a Cristo, "lo que encontramos con causa atribuámoslo a la humanidad, pero lo que es simple y sin causa, pongámoslo a cuenta de la divinidad" Porque entre los seres la divinidad es sin causa (anaítion), porque la causa sería más antigua que Dios. En cambio, hay una causa de la humanidad que Dios asumió por nosotros: el salvarnos.

(112) Igualmente la causa primera sería el Padre en 31, 30 cuando pone los dichos más humildes de la Escritura sobre el Espíritu, como el ser dado o enviado. Estos hay que referirlos a la causa primera, de forma que se muestre que vienen de ella y no tres principios divididos politeísticamente, porque es igualmente impío confundir respecto a la persona, a la manera de Sabelio, como separar las naturalezas, a la manera de Arrio. Y según 30, 16, "el conocimiento de lo más grande sea referido a la causa para honra del que engendra" (cf. Mc 13, 32). Norris (op. cit., 45s), siguiendo a Meijering, verá inconsistencia en esta doble aplicación de aitía, tanto a Dios respecto a la creatura, cuanto al Padre respecto al Hijo y al Espíritu, y dirá que se debe a explanaciones ad hoc de problemas que Gregorio encuentra en la Escritura y tradición. Yo creo que ese doble uso se debe más bien a un reflejo del misterio trinitario.

(113) En Orat 42, 15 dice: "Hénosis dè ho Patér, ex hoû kaì pròs hòn anágetai tà hexêes"

(114) 30, 7.19; 31, 7, etc. Véase 28, 9. Según 29, 3, el Hijo y el Espíritu, aunque eternos, no son ánarja respecto a la causa, el Padre; sí (pos) respecto al tiempo. Cf. p. e. Orat 25, 15; 38, 2.13; 39, 12. Según 29, 10, ánarjon por naturaleza no es lo mismo que el creado. En 31, 23, anárjon, que junto con agénneton los adversarios refieren a la naturaleza divina, Gregorio dice que solo están implícitos en la Escritura. La Escritura llama al Hijo 'principio' (29, 17; véase p. e. Orat 20, 7). Según Orat 42, 15, "el nombre para el sin principio es Padre, para el principio es Hijo, para el que está con el principio, Espíritu Santo".

(115) 29, 11. Según 29, 12, 'inengendrado' no es lo mismo que theós, porque es más absoluto, usándose theós como Dios de todos, es decir en relación a otros. Cf. Norris ad 1. c.

(116) Este es más bien de los adversarios en cuanto que por demasiado amor al Padre niegan la divinidad del Hijo $(29,11)$.

(117) Opina Norris (op. cit., 157s): "Oration 29 gives the clearest evidence of Nazianzen's education in logic. He has a command of dialectic that is too often overlooked. Although his attacks on the later Arians do not all hit the mark, he is repeatedly on target. Time after time he demonstrates 
del Hijo, que había sido negada por arrianos. Lo primero que habría que decir es que el engendramiento del Hijo es un misterio insondable que solo lo conoce Dios. La generación no es la forma carnal que nosotros conocemos. No es corporal (118); es exenta de pasión (119). Gregorio insistirá mucho en que no hay un corte de substancia (120), que, por lo demás, es simple y única. Según 31, 7, hay que llamarlo Hijo porque viene de Dios y es consubstancial, pero hay que aplicar metafóricamente a lo divino, los nombres de aquí abajo, especialmente los de parentesco (121).

Gran objeción de Eunomio es que la esencia de Dios es agénneton, luego el gennetós es creatura. Como hemos visto, a esto responde Gregorio que no podemos ni conocer ni decir lo que Dios es, y agénneton es la propiedad del Padre (122). Según el adversario (123), inengendrado y engendrado no es lo mismo. Luego si uno es Dios, el otro no lo es. Gregorio responde que engendrador y engendrado son lo mismo según la naturaleza (124) y se dividen en torno a la substancia. El inengendrado es Dios, pero el engendrado también es Dios, porque viene de Él. Y si es tan grande para el Padre no venir de nadie, no es menos grande para el Hijo venir de tal Padre: participa de la gloria del sin causa y agrega la veneración de la generación (125). Si arguyen que, si es Dios, es inengendrado, vuelve a responder que inengendrado no es la substancia de Dios y que la diferencia está en torno a la substancia (126).

that his education in philosophical rhetoric prepared him to deal with logical fallacies as well as contextual, grammatical mistakes. His case against the Eunomian lack of education is well taken. ...Perhaps the greatest strength is again his delicate sense of the relationship between faith and reason. Once more he insists on confession and worship as the milieu. 'Faith gives fullness to reasoning'. Although he is prepared and does argue with his detractors about the nature of reason and logic, pointing out their misunderstanding of basic paideia, he demands the priority of faith". "If they (los arrianos) grasped both the limitation of the human mind in speculative or contemplative matters and knew the proper principles of logic, rhetoric and grammar, they would not reach theirs conclusions" (Ib., 34). "Gregory was fundamentally a confessional theologian, a preacher of the gospel" (Ib., 36)

(118) 29, 2.8, etc. Los que objetan son gente con ideas corporales $(29,8.13 ; 31$, 7, etc.). Véase 29, 4; $30,20$.

(119) 29, 2.4.20; 30, 20. Es una generación inefable y divina. Se trata de una generación espiritual. "Para el que no tiene el mismo ser (tautón) que nosotros, también el engendrar es diferente" (29, 4). Si su adversario no es capaz de comprender la generación humana, ¿cómo pretende comprender la divina? "Que la generación de Dios sea honrada con el silencio" $(29,8)$. La forma de esta generación no la conocen los ángeles. La conoce el Padre y el Hijo (Ib.). Véase 29,11; 31, 8. Aun su generación según la carne, es diferente (la Virgen Madre de Dios [theotókon]) (29, 4). En Ep 101, 16 dirá que el que no acoge la theotókos está separado de la divinidad.

(120) Cf. p. e. 29, 8; 31, 11. Véase 27, 6;29, 2.

(121) Es Hijo según una relación más elevada. Según 30, 20 es unigénito porque (viene) monotrópos y no como los cuerpos.

(122) Cf. 29, 2.10 (insinúa aquí también que si las propiedades de la esencia fueran la substancia de Dios, en El habría varias substancias).11.12; 31, 7.8.29.

(123) $29,10$.

(124) Véase también 29, 15; 30, 20.

(125) 29, 11. Cf. 30, 7. Véase 30, 20. En Orat 23, 7, Gregorio pregunta a su adversario: “¿Quién deshonra más a Dios: el que lo pone como principio de estas cosas, como las que tú mismo introduces [el Hijo y el Espíritu, creaturas] o el que lo pone, no como principio de estas cosas, sino de cosas semejantes en la naturaleza y de la misma gloria, como nuestra doctrina (lógos) quiere?"

(126) 29,12 . No necesitas ser padre de tu padre para ser lo mismo en cuanto la substancia (basta con ser hijo). Además el término inengendrado es más absoluto que el término Dios, que dice relación a aquellos de quienes es Dios. Igualmente sería oponer una posesión (engendrado) a una privación (inengendrado). 
Otra gran objección (127) es referente al tiempo, porque Padre parece decir una anterioridad respecto al Hijo. Gregorio responde en 29, 3 que el Hijo y el Espíritu existen desde que existe el Padre, y no hubo un tiempo (hóte) en que el Padre no existiera. El Hijo ha sido engendrado cuando el Padre ha sido inengendrado. Y el Espíritu procede (ekpepóreutai) cuando el Hijo no procede (ouk ekpeporeútai). El Hijo ha sido engendrado atemporalmente. Queriendo expresar lo que está por sobre el tiempo, no se puede evitar la imagen temporal. Lo eterno no es medido ni partido por el tiempo. Y "lo que no tiene principio es eterno, pero lo eterno no es del todo sin principio, en cuanto se refiere al principio, que es el Padre. Pues no son [Hijo y Espíritu] sin principio en cuanto a la causa" (128). En cierto sentido, ellos son principio respecto al tiempo, porque es el tiempo el que viene de ellos (129). Y según 29, 5, el Padre no comenzó a ser padre, porque no tuvo comienzo (130). Pero, ¿engendrar y ser engendrado no introduce un comienzo? No, porque ha sido engendrado desde el comienzo (131). Pero, según 29, 9, se le objeta que no se puede engendrar lo que ya existía. A esto responde, rechanzando la cuestión, porque concurren (súndromon) con el existir, el ser engendrado y el 'desde el comienzo', porque no hay nada anterior a 'desde el comienzo'. En 29, 13 se le objeta que si Dios ha cesado de engendrar (para que la generación sea perfecta), es que ha comenzado. Responde que el alma y la naturaleza angélica no cesarán y, sin embargo comenzaron. Y en 29, 17 dirá que no hay nada adquirido o que se agregue después al Padre, al Hijo o al Espíritu. "La perfección no viene por adición" (132). Porque no hubo un tiempo en que el Padre estuviera sin Logos (álogos) (133) o que no fuera Padre. Y en 31, 4 agrega que a Dios no le puede faltar 'lo santo', porque sería incompleto, imperfecto. Luego tiene que tener el Espíritu Santo desde el comienzo (134). Por otro lado en 30, 4 aparecen las objeciones por las citas bíblicas con 'hasta qué', p. e. 'que el reine hasta que' en 1 Co 15, 25. Responde con 'su reino no tiene límite' y que 'héos' no excluye el futuro que va más allá. Además, el operar la sumisión es reinar sobre nosotros (135) y eso es hasta que se levante para juzgar.

Alguna otra objeción de la Orat 29, ya ha aparecido en algún otro tema de este trabajo, como la que ya vimos sobre si el Padre es nombre de substancia o de acción, a la que Gregorio respondía diciendo que es nombre de relación; o son

(127) Otra objeción es si el Padre engendra queriendo o no queriendo; y si queriéndolo, sería hijo de la voluntad y no del Padre $(29,6 s)$. Gregorio pregunta al adversario si él es hijo de su padre o de la voluntad de este, si Dios creó queriendo o no (entonces el problema sería el mismo si el Hijo fuera creado), y si es Dios es queriéndolo o no. El generado pertenece al que lo engendra y no a la generación. Y en el caso de Dios probablemente la generación es la voluntad de engendrar. No hay nada intermedio.

(128) 29, 3. La causa no es del todo anterior a ellos, como el sol no es anterior a la luz.

(129) Véase también Orat 20,7, etc.

(130) En diferencia a nosotros, es propiamente (kuríos) padre, porque no es padre e hijo a la vez. Igualmente el Hijo es propiamente hijo. Según Orat 25, 16, es totalmente Padre de todo el Hijo. Según Orat 20, 6, negar la divinidad del Hijo es suprimir también que el Padre sea.

(131) La Escritura a veces cambia los tiempos.

(132) $29,17$.

(133) O sin verdad, sabiduría, poder, o privado de vida, o esplendor, o bondad. Gregorio dice esto después de enumerar diversas citas bíblicas que claramente se dicen del Hijo.

(134) Es el tiempo lo que nos separa de Dios.

(135) Estará con nosotros hasta la consumación del siglo (Mt 28, 20). Cf. 30, 45. 
objeciones referentes a textos concretos de la Escritura, que veremos después. Por ahora solo quiero detenerme en dos más. La primera es reconocer que el Hijo es Dios según la Escritura, pero este término sería usado en sentido equívoco (solo es común la designación), y no en sentido propio (136). Los términos equívocos se aplican a ambos casos en sentido propio (kuríos); se trata de naturalezas diferentes. Pero responde Gregorio, si son naturalezas diferentes no se las está comparando como si fuera una mejor o anterior o más que la otra. El perro de tierra firme no es más perro que el de mar o viceversa. Pero en el caso que tratamos, por un lado, en tus palabras le concedes la semejanza con el Padre y, por otro, lo pones debajo atribuyéndole un segundo lugar en la honra y adoración. Si tienen el mismo nombre, que tengan el mismo honor de las naturalezas (137).

La segunda objeción (138) reza así: si decimos nosotros que 'el Padre es más grande que el Hijo en cuanto a la causa', el adversario agrega 'la causa es por naturaleza', concluyendo que el Padre es más grande por naturaleza. Responde Gregorio que no se puede pasar lógicamente de ser más grande por la naturaleza de la causa, a ser más grande por naturaleza (139), como que lo dicho de un hombre no se puede simplemente afirmar sobre el hombre en general. Esta objeción vuelve, a propósito de la Escritura, en 30, 7. Gregorio responde que no solo es dicho más grande sino también igual. "¿No es evidente que 'más grande' pertenece a la causa y que 'igual', a la naturaleza?” (140).

Y en la Escritura se afirma, pues, claramente la divinidad de Cristo (141). Lo que se dice de él que no sea digno de Dios (142), es en cuanto hombre. "Por una parte lo

(136) 29, 13 (véase 29, 18). Comentando este párrafo a partir de frases anteriores, dice Norris (op. cit., 149): "According to his (Gregorio) judgment, if an individual deserves inclusion within a species, then it should not be given the name of species in an equivocal fashion. The 'facts', prágmata, will determine that judgment. When they are known, the name follows".

(137) $29,14$.

(138) 29,15 .

(139) Anota Gallay: Le faux raisonnement fait que l'on passe d'une affirmation avec restriction à une affirmation sans restriction. Es diferente la naturaleza del Padre en cuanto Padre (que antecede, bajo el aspecto de causalidad, a aquel que Él engendra) de la naturaleza de Dios.

(140) También alguien puede decir que no es menor venir de una tal causa que ser sin causa. Participa de la gloria del sin principio, porque viene del sin principio, a lo que agrega la generación, hecho tan grande y venerable. Porque decir que el Padre es más grande que el Hijo considerado en cuanto hombre, es verdad, pero no gran cosa.

(141) Se lo llama Dios, Logos, 'el que está en el principio (en arjê $\underline{\mathbf{e}}_{\mathbf{i}}$ ), con el principio, el principio', Hijo unigénito, camino, verdad, vida, luz, sabiduría, poder, resplandor, impronta, imagen, sello, señor, rey, el que es, el omnipotente $(29,17)$, etc. En 30, 20 explica la mayoría de estas palabras, añadiendo, justicia, santificación, redención y resurrección. Destaco algunas. Se lo llama Hijo porque es lo mismo que el Padre en cuanto a la substancia y viene de Él. Como Logos expresa (exaggeltikón) al Padre, sería como su definición (hóros). Es una demostración de la naturaleza del Padre, "porque todo engendrado es el lógos silencioso del que lo ha engendrado". Está en los seres, porque todo tiene consistencia en Él (como dúnamis conserva y sumistra la fuerza de cohesión). Como Creador no desconoce los lógous de los que hizo (nada antecede para Él a los logikoí, según 28, 11). Imagen en cuanto consubstancial y porque Él procede del Padre y no al revés: imagen viviente de un viviente. Por la naturaleza de lo simple, no se trata de parecido sino que todo entero se es impronta de todo entero, y de que es lo mismo, más que de una semejanza (afomoíoma). Vida, porque luz y consistencia y donante de existencia (ousíosis) de toda naturaleza logikés (Hch 17, 28). Tiene doble poder de insuflar, dándonos el soplo (pnoén) y el Espíritu Santo. Redención en cuanto nos libera a nosotros retenidos por el pecado, dándose a sí mismo a cambio por nosotros como rescate que purifica la tierra. Véase $30,3$.

(142) Hace una lista de estos dichos en 29, 18. 
más elevado atribúyelo a la divinidad, a la naturaleza superior a las pasiones y al cuerpo. Por otra, lo más humilde al compuesto (t $\underline{\mathbf{o}}_{\mathbf{i}}$ sunthéto $_{\mathbf{i}}$ ), al que por ti se anonadó y se hizo carne ...y se hizo hombre. ...y comprendas lo que se dice de la naturaleza y lo que se dice de la economía" (143). Y en 30, 2-16, interpreta 10 tipos de textos que no parecen dignos de Dios, de algunos de los cuales ya hemos tratado. El primero $(30,2)$ es el texto de $\operatorname{Pr} 8,22$ (éktise). 25 (gennâ $_{\mathbf{i}}$ ). Concede que no se trata de una personificación de la Sabiduría, sino del Salvador. Lo con causa hay que atribuirlo a la humanidad, y lo simple y sin causa a la divinidad. Por tanto, la Sabiduría es creada según su generación aquí abajo; y engendrada según su generación primera y más incaptable (144). Dentro de la segunda objeción sobre el fin del reinado, que ya vimos por el aspecto temporal, está que el Hijo se somete al Padre $(30,5)$, pero eso es porque como cabeza de todo el cuerpo hace suya mi insumisión, que termina cuando haya completado la sumisión, presentándome a mí salvado (145). Igualmente en su 'Dios mío, por qué me has abandonado' (146), nos representa a nosotros; se ha apropiado nuestra sinrazón y nuestro pecado. Asimismo $(30,6)$ cuando se dice que aprendió obediencia por lo que padeció, etc. El realiza este rol (dramatourgeîtai) y entrelaza estas cosas maravillosamente por nosotros. En cuanto Logos no era ni obediente ni desobediente, porque esto es propio de los dependientes. "Pero, en cuanto forma de esclavo, el desciende hacia sus consiervos y esclavos y toma una forma ajena, llevándome a mí con lo mío íntegramente en Él, a fin de consumir lo peor, como el fuego a la cera, como el sol la bruma y que yo participe de las cosas de Él, gracias a esta mezcla" (147).

La cuarta objeción a partir de la Escritura $(30,8)(148)$ es el texto en que Jesús habla de 'mi Dios', que va junto con 'mi Padre' en Jn 20, 17. Responde Gregorio que no es Dios del Logos (que es Dios) sino del visible (Jesús), como no es Padre del visible sino del Logos. Porque Cristo era doble (diploûs). Entonces del que se ve, como de nosotros, impropiamente se habla de Padre (149). Los nombres se intercambian a causa de la mezcla (súgkrasin). Cuando las naturalezas (150) son distinguidas en nuestros pensamientos (taîs epinoíais), los nombres también son separados. Ambos juntos (sunamfóteron) son uno, no por la naturaleza sino por la unión (sunódo $\underline{\mathbf{o}}_{\mathbf{i}}$ ). La quinta objeción $(30,9)$ es que Cristo recibe la vida, etc. Gregorio responde que esto corresponde a la humanidad (151).

(143) 29, 18. Cf. 30, 1.21. Véase p. e. Ep 102, 24-27.

(144) Así es llamado doûlos y paîs Theoû $(30,3)$.

(145) “Así sometiéndolo presenta a Dios lo sometido, haciendo que lo nuestro sea de Él” (30, 5). Igualmente fue llamado maldición y pecado y llega a ser nuevo Adán.

(146) Según Norris (ad 1. c.), "The subject who is not forsaken by the Father or his own Godhead must be the human Jesus. Thus Nazianzen can speak of the man Jesus as the subject"

(147) También se puede suponer que fue para darse cuenta (dokimázei) de nuestra obediencia y medirlo todo con sus padecimientos, etc. En el mismo sentido habría que interpretar el texto de $\mathrm{Hb} 2$, 18. El escapó del todo [a estos asaltos]; nosotros, en cierta manera, somos vencidos. Poque es más gran cosa que él sea atacado (tò diojthênai), que nosotros seamos vencidos.

(148) La tercera $(30,7)$, ya tratada, es que el Padre es más grande

(149) Según mi probable interpretación, 'Dios' se dice propiamente (kuríos) de los dos, del Logos porque es Dios, y del que se ve en cuanto se habla del Dios del que se ve. En cambio 'Padre' no se dice propiamente en relación al que se ve. En 30, 15 interpreta 'Hijo' como dicho de Cristo en cuanto hombre, gracias a que es usado absolutamente.

(150) "Dos naturalezas que concurren a uno solo, no dos hijos" (Orat 37, 2). Cf. Ep 101, 19, etc.

(151) Si se refiriera a Dios, serían cosas ya existentes desde el comienzo y en razón de la naturaleza, no por gracia. 
La novena objeción $(30,14)$ es que está siempre vivo para interceder por nosotros. Responde que como único mediador (el hombre Jesucristo) interviene aún ahora como hombre por mi salvación (152). Porque está con el cuerpo que asumió (153). Y así es nuestro paráclito (154) La décima objeción $(30,15)$ es que no conoce el último día ni la hora (155). Es evidente, responde, que conoce en cuanto Dios y dice ignorar en cuanto hombre (156). Y prosigue en 30, 16: El Hijo no lo conoce de otra manera que como lo conoce el Padre. Esto no es conocido por nadie, sino por la naturaleza primera. Añade Gregorio que falta tratar de otras cosas como recibir órdenes, ser exaltado, aprender obediencia por el sufrimiento, ser sumo sacerdote, ser entregado, suplicar, sufrir la agonía, etc. Todas estas expresiones conciernen a lo que sufre (tò pásjon), y no a la naturaleza inmutable y que está por encima del padecer (157) Y termina la $O r$ 30: "Jesucristo ayer y hoy corporalmente, él mismo espiritualmente y por todos los siglos. Amén" (158).

Veamos, finalmente, otras objeciones a partir de la Escritura, cuyas respuesta irían más allá de la distinción entre lo divino y lo humano. Así, a la sexta objeción de que el Hijo no puede hacer nada si no ve al Padre haciéndolo, después de hablar de los diversos sentidos de posible (dúnasthai) o imposible, Gregorio responde en 30, 11, que todo es común a ambos, también el existir (tò eînai) y la igual dignidad, aunque el Hijo, en su existir ajrónos kaì anaitíos, lo tenga del Padre. No es que copie lo ya hecho por el Padre (159), sino que de los mismos actos el Padre señala los modelos y el Logos los realiza con ciencia y como amo, o más exactamente a la manera del Padre, con la misma dignidad de poder (exousías). Así el gobierno (oikonomían) y su conservación de lo creado. La séptima objeción $(30,12)$ es que descendió para hacer la voluntad del que lo envió. "El querer del Salvador no era opuesto a Dios, estando íntegramente divinizado" (160). Esto se muestra en la Oración del Huerto que no era del asumido sino del asumente. No bajó a hacer su voluntad. "Pero "no es que haya una voluntad propia del Hijo al lado de la del Padre" (161). Porque no hay una voluntad separada de la del Padre sino común con

(152) "También se dice del Espíritu que intercede por nosotros" (Ib.)

(153) Pero ya no es más conocido como hombre, es decir con nuestra pasiones carnales salvo el pecado.

(154) Con lo que sufrió como hombre me persuade, como Logos y consejero, a aguantar. Esta es su acción de paráclito.

(155) “Cómo va a ignorar algo el que es la Sabiduría, Creador de los siglos, el consumador, el que transforma, el que es el fin de todo lo hecho, el que así conoce lo de Dios como el espíritu del hombre lo de en este?” ¿Cómo conoce con exactitud lo que sucederá antes de la hora y lo del tiempo del final, si ignora la hora?

(156) Si se separa lo que aparece de lo inteligible (noouménou)

(157) En 30, 21 enumera los nombres que convienen a lo asumido de entre nosotros: hombre (cuerpo, alma y espíritu, pero sin pecado; nos es accesible por su cuerpo, Dios visible), Hijo del hombre (por Adán y por la Virgen, pero no según la ley de la generación), camino, puerta, pastor, oveja (como sacrificada), cordero, sumo sacerdote, Melquisedec (sin madre según lo superior a nosotros; sin padre según lo nuestro). "Es Cristo a causa de la divinidad. Porque la unción de la humanidad, que santifica, no es por la operación como en los otros 'cristos', sino por la presencia íntegra del que unge. Y esta presencia hace que sea llamado 'hombre' el que unge y haga Dios al ungido" $(30,21)$. Véase 30,1

(158) 30, 21. La gloria también es a Cristo en 27, 10; 29, 21. En cambio en 31, 33, es a la los tres y a la única divinidad y poder.

(159) Como si el Padre antes hubiera librado de los demonios y de las enfermedades, etc.

(160) El nuestro, sí, se opone lo más a menudo.

(161) $30,12$. 
él. "Como hay una sola divinidad, así un solo querer" (162). Lo que se dice del Padre se refiere también al Hijo (163). Así la voluntad del Padre. En la respuesta anterior Gregorio ha pasado a que cosas que se dicen del Padre (de Dios) también implican al Hijo, y así resuelve la octava objeción $(30,13)$ : que conozcan al único Dios verdadero (164) y a su enviado; nadie es bueno sino solo Dios (165). En la segunda objeción $(30,6)$, nos habla de un 'Dios' dicho indistintamente, que implica al Hijo, al tratar del texto 'Dios será todo en todos'. Porque ese 'Dios' no se refiere al Padre como si el Hijo se disolviera totalmente en él, como intentan interpretar los sabelianos, sino que se refiere a todo Dios, en manera indeterminada (aorístos) (166): nosotros íntegros seremos semejantes a Dios (theoeideîs), y podremos contenerlo (joretikoí) y a él solo.

Junto con esta larga defensa de la divinidad de Cristo, ha ido afirmando Gregorio su plena humanidad, cuanto nosotros somos, excepto el pecado (167). Hecho todo para todos (hupèr pánton). Así es cuerpo, alma y espíritu, cuyo conjunto es un hombre (168). Así une lo condenado a Él, para liberar (lúse ) todo de la condenación (169). En este mismo párrafo dice que es hombre para santificar por sí mismo al hombre, llegado a ser como la levadura para toda la masa. Y hacia el final añade: "para que llegues a ser Dios subiendo desde abajo, por causa del que de arriba bajó por nosotros" (170). El nos hace Dios en virtud de haberse hecho hombre (dunámei tê̂s enanthropéseos) (171).

(162) $\mathrm{Ib}$.

(163) Está dicho apò koinoû. Cf. cita referente a Jn 14, 24. Dios le da a Jesús el Espíritu, sin medida $(30,12)$.

(164) "Está dicho para quitar a los que no son dioses y, sin embargo, así son llamados" (30, 13). La divinidad les es común. Aplica los textos de Ba 3, 36.38 a Cristo (que convivió con nosotros corporalmente). Según esto, el implicado ahí sería el Padre.

(165) Igualmente las objeciones que provendrían de $\operatorname{Rm~16,27;1Tm~6,~16;~1,~} 17$.

(166) Pablo, en Col 3, 11, lo limita a Cristo. También Gregorio se había referido a que ciertas palabras que se atribuyen a Dios no están explícitas en la Escritura sino implicadas. Igualmente, 'hasta' del reino de Cristo en 1 Co 15,25 no excluye el futuro $(30,4)$.

(167) Según Orat 38, 13, Cristo es uno de dos opuestos, carne y Espíritu, de los que uno diviniza y el otro es divinizado". "Lo que era, anonadó; lo que no era, asumió" (Orat 37, 2).

(168) 30, 21 (cf. Orat 45, 9). Si es visible por el cuerpo, también es Dios dià tò nooúmenon. Véase Orígenes, Dial Her, 7. Cf. p. e. Ep 101, 15 (El mismo, hombre todo entero y Dios). Según Ep 101, 19, "dos naturalezas, Dios y hombre, porque y alma y cuerpo, pero no dos hijos ni dioses". Según Ep 101, 48s, Dios se liga a la carne por medio del noûs (cf. 29, 19; Orat 2, 23; 38, 13, etc.). Véase Ep 101, 36; De vita sua, 624-651. Según Ep 101, 32, Tò gàr apróslepton,

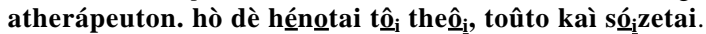

(169) Según 30, 5, antes nosotros estábamos abandonados y despreciados; ahora estamos asumidos y salvados por los sufrimientos del impasible. Se apropió (oikeioúmenos) nuestra sinrazón y nuestro pecado. Según 40, 45, era "impasible por la divinidad, pasible por lo asumido".

(170) 30, 21. Cf. 29, 19. Fue exaltado para que aprendas a ascender con la divinidad (29, 18). Respecto a la divinización, puede verse D. F. Winslow, The Dynamics of Salvation. A Study in Gregory of Nazianzus (Patristic Monograph Series, 7), Cambridge, Mass. 1979.

(171) 30, 14. Véase 30, 6. "El participa de mi carne para salvar la imagen, inmortalizar la carne; por segunda vez se une (con nosotros) (koinoneî) en forma mucho más maravillosa que la primera (Orat 45, 9). "El hombre de aquí abajo (llegó a ser) Dios, puesto que se mezcló (sunakekráthe) con Dios, y llegó a ser uno, habiendo prevalecido (eknikésantos) lo mejor, para que yo llegue a ser tanto Dios, cuanto Aquel, hombre" (29, 19; cf. Orat 40, 45, etc.). Respecto a la devoción personal de Gregorio por Cristo, cf. F. Trisoglio, op. cit., 128-130. 
Insistiendo en la humanidad, dice en 30, 3: realmente estaba sometido (edoúleuse) a la carne, las pasiones (páthesi), las nuestras (172) (por nuestra libertad), y a todos a los que, retenidos por el pecado, salvó. Así la bajeza del hombre ha sido entrelazada con Dios y llega a ser Dios por la mezcla (míxeos). Ha sido visitado de tal forma por el sol saliente de lo alto, que lo engendrado santo es llamado Hijo del Altísimo y se le regala un nombre sobre todo nombre, el de 'Dios', y toda rodilla se dobla ante el que se vació (kenothénti) por nosotros y que mezcló (sugkerásanti) (173) la imagen divina con la forma de esclavo (174). Es, por nosotros, el Dios pasible contra el pecado (175).

Destacando los contrastes divino-humanos de Cristo (176) exclama en 29, 19s: "Porque aquel que ahora es despreciado por ti, era en otro tiempo y por encima de ti. El que ahora es hombre, era sin composición. El que era, ha permanecido; y el que no era, fue asumido. En el comienzo era sin causa (anaitíos). Porque ¿cuál es la causa de Dios? Pero después llega a ser por una causa. Esta era salvarte a ti, insolente, quien por esto desprecias la divinidad, porque acogió tu espesor, asociándose a una carne por intermedio del noûs. Y el hombre de aquí abajo llegó a ser Dios, después de que se mezcló con Dios (sunanekráthe ), y llegó a ser uno, dominando lo mejor, para que yo llegue a ser Dios tanto cuanto aquel, hombre. Fue engendrado, pero también había sido engendrado; de mujer, pero también virgen. Esto humano; aquello divino. Sin padre aquí, pero sin madre allá. Todo esto de parte de la divinidad (177). Fue llevado en el vientre, pero reconocido por un profeta que también era llevado en el vientre y saltó delante del Logos, por el que fue hecho", etc. "El fue bautizado como hombre, pero absolvió los pecados como Dios, y a fin de santificar las aguas. El fue tentado en cuanto hombre, pero venció en cuanto Dios y manda tener confianza como quien ha vencido al mundo. ...El suplica, pero escucha favorablemente ...Pregunta dónde se ha puesto a Lázaro, porque era hombre, pero resucita a Lázaro, porque era Dios. El es vendido y a precio demasiado barato: treinta piezas de plata; pero Él rescata al mundo y a gran precio: el de su propia sangre. ...Como cordero no tiene voz, pero es el Logos, anunciado por la voz del que grita en el desierto. ...Él muere, pero vivifica y destruye con su muerte la muerte. Es enterrado, pero resucita. Desciende al Hades, pero conduce hacia arriba a las almas, pero asciende al cielo, pero vendrá a juzgar a vivos y muertos" (178).

(172) Véase también 30, 14.

(173) En $E p$ 101, 22 hablará de kat' ousían sunêfthaí te kaì sunáptesthai. Y en Ep 101, 31: “Así como las naturalezas están mezcladas, así también las denominaciones, y se compenetran

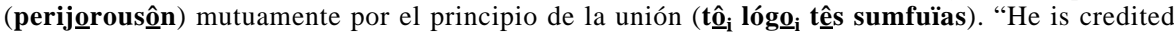
with being the first theologian to employ some form of perijóresis, 'interchange' or 'to interpenetrate', for the two natures of Christ" (Norris, op cit., 50).

(174) Dios lo ha hecho Señor y Cristo. Esto se produjo por la actividad del engendrado y la benevolencia del engendrador.

(175) 30, 1 (katà tês hamartías). Véase, p. e. Orat 43, 64 (Dios crucificado). Respecto a la obra redentora de Cristo, puede verse H. Althaus, Die Heilslehre des heiligen Gregor von Niazanz (Münsterische Beiträge zur Theologie, 34), Münster 1972, cap. 8.

(176) Véase también p. e. 29, 19; Orat 38.2.13

(177) Hólon toûto theótêtos.

(178) Ib. Comenta Norris (ad 1. c.): Because Nazianzen develops thematically the dominance of Jesus Crhist's divinity, there are times when the humanity is not given its due. Este mismo autor (Ib., p. 48 n. 236) trae los pasajes, cuyas expresiones, según Mason, alguien podría calificar de naciente 
Finalmente, Gregorio compara, en su primera carta a Cledonios, la verdad cristológica y la trinitaria, de la siguiente manera: "Y para decirlo brevemente, lo uno y lo otro, de lo que está [formado] el Salvador... y no el uno y el otro. ¡Lejos de eso! Porque ambas cosas son uno por la unión (sugkrásei), Dios que se hace hombre y el hombre que se hace Dios, o como se lo quiera nombrar. Pero digo lo uno y lo otro, contrariamente a lo que tiene lugar en la Trinidad. En ésta (decimos), por una parte, el uno y el otro para que no confundamos las hypóstasis; y no, por otra parte, lo uno y lo otro, porque los tres son uno y lo mismo por la divinidad" (179).

\section{3) LA CONSUBSTANCIALIDAD DEL ESPÍRITU}

Los saduceos no admitían al Espíritu Santo. Los mejores teólogos de los griegos lo entrevieron (efantásthesan), pero difirieron sobre su nombre (180). Algunos de nuestros sabios lo concibieron como actividad (enérgeian), otros como creatura, otros como Dios, otros no se decidieron ni por uno ni por otro, por respeto a la Escritura, que no lo revela claramente (181). No se dirigirá a los que niegan la existencia del Espíritu ni a los griegos (182) en su Orat 31. La divinidad del Espíritu era atacada, con cierta consecuencia, por los que negaban la divinidad del Hijo (183); y además por los que solo negaban la divinidad del Espíritu (184). Estos últimos, que no están tan mal como los anteriores, caen en la contradicción de reprochar que sean tres los que son Dios, pero admitir dos, es decir, de achacar a los ortodoxos el triteísmo, sin darse cuenta de que entonces ellos estarían en el diteísmo (185). Gregorio responde, como ya hemos visto, que hay un solo Dios, porque hay una sola divinidad. "Y hacia la unidad (pròs hèn) se vuelve (tèn anaforàn éjei) lo

nestorianismo. Ellos son: 29, 18.19; 30, 1.2.3.7.8.9.10.12.13.21. Pero, a mi parecer, en alguno de ellos el contraste parece estar más bien entre Cristo Dios y Cristo encarnado. Afirmaría tanto la distinción como la unidad, pero con un lenguaje todavía no maduro y en que falta la única hupóstasis de Calcedonia. Según Norris $(I b ., 50)$, "He can distinguish between the humanity and divinity as subjects, but he can also attribute everything to one person because of the intermingling".

(179) Ep 101, 20s. Según A. Grillmeier (Jesus der Christus im Glauben der Kirche. I:Von der Apostolischen Zeit bis zum Konzil von Chalcedon (451), 2a ed., Freiburg 1982, p. 538), "zum erstenmal in der griechischen Theologie findet sich die Anwendung der trinitarischen Begriffssprache auf die christologische Formel, doch nur innerhalb einer untechnischen Terminologie". Y después dirá (Ib., 539): "Ihm übrigen ist die Christologie Gregors von Nazianz nicht so sehr aus der theologisch-spekulativen Reflexion geboren als vielmehr aus seiner religiösen Spiritualität. Denn in seinem Blick steht die Idee der Vergöttlichung des Menschen, wofür die Vergöttlichung der Menschennatur Christi das theologische Fundament liefern soll".

(180) Noûs del universo, noûs exterior, etc.

(181) 31, 5. Algunos admiten los tres de la siguiente manera: "uno es infinito por la substancia y el poder; otro es infinito por el poder, pero no por la substancia; y el otro es limitado en ambos aspectos". Imitan, de otra manera, a los que los nombran demiurgo, colaborador (sunergón) y servidor (leitourgón), y que piensan que hay una conformidad entre el orden (táxin) en los nombres y la cualidad de las realidades.

(182) 31,6 .

(183) Véase también 31, 2.

(184) Véase también 31, 24.

(185) 31,13 (véase 31,1.10). Los argumentos que usan ellos para defenderse de ser diteístas, pueden servir para defenderse de ser triteísta. 
que viene de él, aunque sea creído que son tres", etc. (186). Alguno podría objetar que la única divinidad, como la única humanidad, está solo en el pensamiento (epinoía $_{\mathbf{i}}$ ), pero hay muchos dioses y muchos hombres bien diferentes. Así, los dioses de los griegos están en conflicto o se reparten el universo. Responde Gregorio que cada uno está tan unido (tò hèn éjei) con el otro como consigo mismo, por razón de la identidad de substancia y del poder (dunámeos) (187). A esto sigue la objeción de que los consubstanciales son los que se suman, por tanto, tres dioses (188). Gregorio responde: ni los consubstanciales se suman necesariamente (189), ni los no consubstanciales dejan de poder sumarse (190). El número indica la cantidad de los 'sujetos' (hupokeiménon) y no la naturaleza de las realidades (191).

Sin el Espíritu Santo la divinidad sería incompleta, porque le faltaría la santidad. Y esto desde el comienzo (192). Gregorio está tan confiado en la divinidad del Espíritu (193), que se atreve a aplicar las mismas expresiones a la Trinidad. Así, el ser "la verdadera luz que ilumina a todo hombre que viene al mundo", lo aplica al Padre, y al Hijo y al otro Paráclito. Igualmente aplica 'era' y 'luz'. "De la luz, el Padre, captamos la luz, el Hijo, en la luz, el Espíritu” (194).

Una de las grandes razones de la divinidad del Espíritu es que nos diviniza. Si fuera creatura, ¿cómo me hace a mí Dios? (195). "Del Espíritu nos viene la regeneración; y de la regeneración, la remodelación (anáplasis); y de la remodelación el conocimiento de la dignidad del que nos remodela" (196). Otras de las razones fuertes es la fe y el culto. De hecho Gregorio habla confiando en el Espíritu Santo (197) y

(186) 31,14

(187) $31,15 \mathrm{~s}$

(188) 31, 17-20. Estos, por no defender la monarquía, niegan la divinidad (31, 17).

(189) Puedo decir 'uno', 'uno' y 'uno', sin sumar.

(190) $31,18 \mathrm{~s}$

(191) $31,18$.

(192) 31, 4. Si hubiera habido un tiempo en que el Hijo no existiera, habría habido un tiempo en que el Espíritu no existiera. Entonces el Espíritu sería del mismo rango que yo. Si uno de los tres existía desde el comienzo, también los tres. En Orat 25, 16 llama al Espíritu autoagiótes.

(193) Quiere exaltar el Espíritu sin temor. Según 31, 2, en hablar sobre el Espíritu hay una especial dificultad.

(194) 31, 3. Afirma D. Wendebourg (Geist oder Energie. Zur Frage der innergöttlichen Verankerung des christlichen Lebens in der byzantinischen Theologie [Münchener Monographien zur historischen und systematischen Theologie, 4], München 1980, p. 216): "Der Geist nimmt den dritten Platz ein, die Stelle, an der a) die Tätigkeiten Gottes ihre Zielpunkte erreichen und an der (b) diese umgekehrt mit Gott zusammentreffen. ...Besonders hinsichtlich der Taufe wird das schöpferische Handeln des Geistes mehrfach betont...".

(195) 31, 4. Cf. 31, 6 ; 31, 28 (diviniza (theô̂) por el bautismo); 31, 29. Véase, p. e., Orat 34, 12; 39, 17. El Espíritu habita en los discípulos según la capacidad de los que lo reciben $(31,26)$. Véase 31, 6. Según el mismo número 31, 6, en Él llegamos a ser perfectos (teleioúmetha; véase también Orat 41, 9); según Norris: somos bautizados. Afirma Norris (op cit., 52): "Winslow sees théosis not only as central to Gregory's entire theological enterprise, but also as a creative innovation in terminology on his part. It is certainly the case that the word seldom appears before him and that the understanding distinguishes his view of salvation from that of the later Arians, yet it is also true that he is following the lead of people like Irenaeus, Origen and Athanasius rather than creating a new conception.

(196) $31,28$.

(197) 29, 1. Si Cristo es el que reconcilia, el Espíritu es el que ilumina (analámpseien) (29, 21). El Espíritu enseña (no todo podía ser sobrellevado por los discípulos cuando el Salvador enseñaba) $(31,27)$. 
teniéndolo como guía (198). En Él creemos (eis autó), lo que es propio de la divinidad (199). En el Espíritu adoramos y mediante Él rezamos (200). Y esto le parece que significa que Él presenta a sí mismo la oración (201) y la adoración, dado que "la adoración de uno es adoración de los tres (202), porque en los tres es el mismo honor (203) en dignidad y divinidad" (204). Pregunta Gregorio: "Si el Espíritu debe ser adorado (proskunetón), ¿cómo no es digno de culto (septón) (205)? Y si es digno de culto, ¿cómo no es Dios?” (206).

Pero una gran objeción es que no es explícitamente llamado Dios en la Biblia: Dios extranjero (xenón), que no está en la Escritura (207). Gregorio reconoce que no está escrito muy claramente que el Espíritu sea Dios, como lo está primeramente del Padre y después del Hijo (208). Gregorio responde que en la Escritura hay cosas que no existen y que se dicen, como que Dios se despierta, etc. Hay otras que existen y que no se nombran, como inengendrado, sin principio, inmortal. Porque están implicadas (sunagónton) (209) en otros dichos. Hay otras que ni se nombran ni existen, como que Dios es malo. Finalmente hay otras que existen y se nombran, como Dios, el hombre (210). Por tanto, no hay que esclavizarse a la letra. Hay que mirar más a lo pensado que a lo dicho (211).

Pero la respuesta fundamental es que el actuar de Dios es progresivo (212). Porque Dios procede con cambios parciales, de la condescendencia a la perfección (213). Esto conviene a la moderación de Dios, que no es un poder tiránico. Quería ser benefactor de los que lo aceptan (214). Procediendo como pedagogo y médico, suprime una cosa, tolera otra, hace concesiones. Así fueron los dos grandes cambios (terremotos) de la manera de vivir: de los ídolos a la Ley, y de esta al Evangelio (los dos Testamentos). $\mathrm{Y}$ anunciamos un tercer terremoto que es pasar de las cosas de aquí a las de allá, inconmovibles. Esto, por tanto, no sucedió de súbito ni todo con el primer movimiento. Para que no fuera por fuerza, sino por persuasión (215). A esto

(198) 31, 33. Según 28, 1, el Espíritu inspira en el discurso. Cf. 31, 2. "Por el Espíritu el Padre es conocido y el Hijo glorificado" (Orat 41, 9). Según Orat 2, 39, por el Espíritu se conoce, se interpreta y se escucha a Dios.

(199) 31,6 .

(200) Cita los textos de Jn 4, 24; Rm 8, 26; 1Co 14, 15.

(201) Según 30, 14, no solo Cristo sino también el Espíritu intercede por nosotros.

(202) Son tres los que adoramos $(31,14$; cf. 31, 33). Véase 29, 1; 31, 17.

(203) Homótimon ya ha sido usado respecto al Hijo y al Padre en 29, 18; 30, 11. Cf. 29, 2; 31, 28 , etc.

(204) $31,12$.

(205) Véase también 31, 3 (hò presbeúomen).

(206) 31, 28. Lo uno está ligado a lo otro, como cadena verdaderamente de oro y salvadora.

(207) 31, 1.3.21.29 Cf. 31, 12 (¿Quién lo ha adorado o le ha dirigido oraciones en la Biblia?).

(208) $31,21$.

(209) Palabras son también las del que obliga a decir (toû légein sunanagkázontos) $(31,24)$.

(210) $31,22 \mathrm{~s}$

(211) 31, 24. Véase también 31, 3.

(212) Según Winslow (op. cit., 125), "Gregory appears to be the first patristic author to use this theory of 'progressive revelation' to explain the 'novelty' of a doctrine, a doctrine which in this case asserts the full deity of the Spirit".

(213) Así, primero suprime los ídolos, después los sacrificios, después muestra la circuncisión como una acomodación (oikonomías) respecto a la perfección.

(214) Que no fuéramos constreñidos sino persuadidos.

(215) $31,25$. 
se puede comparar lo que concierne a la teología. Pero aquí no es por supresión o metáthesis, sino que la perfección es por adición (216). "El Antiguo (Testamento) anunció claramente al Padre, más oscuramente (amudróteron) al Hijo. El Nuevo (Testamento) manifestó al Hijo, insinuó (hupédeixe) la divinidad del Espíritu. Actualmente el Espíritu tiene derecho de ciudadanía entre nosotros (217) y nos concede una más clara revelación de sí mismo. Era resbaladizo, cuando todavía no se confesaba la divinidad del Padre, proclamar abiertamente la del Hijo, ni cuando todavía no era aceptada la del Hijo, el Espíritu Santo" (218). Así, por adiciones parciales (219), por ascensiones, por progresos y avances de gloria en gloria, resplandece la luz de la Trinidad para los más iluminados (220). El Salvador mantuvo en secreto algunas cosas que entonces no podían ser sobrellevadas por los discípulos, pero dijo que todo nos sería enseñado por el Espíritu cuando habitara entre nosotros. Gregorio piensa que una de ellas era la misma divinidad del Espíritu, que se aclaró más tarde, cuando el conocimiento ya estaba en su sazón y era sobrellevable, después de la restitución (apokatástasin) del Salvador, ya no más no creído, a causa del milagro (221)

Pero la divinidad del Espíritu está en la Escritura (lían éggrafos) y su divinidad se prueba para los que no son extraños al Espíritu. Cristo es engendrado, el Espíritu lo precede; es bautizado, testifica; es tentado, lo conduce; realiza prodigios, lo acompaña; asciende, lo sucede. ¿Qué no puede hacer de las grandes cosas que son de Dios? ¿Con qué nombre, de los que pertenecen a Dios, no se lo llama, salvo el de ingénito y la génesis? (222). Y todo lo que la Escritura dice de más humilde, como ser dado

(216) dià tôn prosthekộn he teleíosis $(31,26)$.

(217) Véase Orat 41, 11. "Porque, habiendo el Hijo habitado entre nosotros corporalmente, convenía que el Espíritu también se manifestara corporalmente" $(I b$.)

(218) 31,26

(219) 'Iluminaciones parciales' en 31, 27. Este es el orden de la teología: no de golpe, no escondiendo hasta el final.

(220) 31, 26. Así habita (epidemeî) parcialmente en los discípulos según la capacidad (dunámei) de los que lo reciben: al comienzo del Evangelio, después de la pasión, después de la ascensión, perfeccionando las capacidades (tàs dunámeis epiteloûn; Norris traduce "he performs miracles"), insuflado, aparecido en lenguas de fuego. Así el Espíritu es manifestado poco a poco por Jesús: El pedirá al Padre, quien enviará otro Paráclito, el Espíritu de la verdad. Después: lo enviará en mi nombre. Después: ‘yo lo enviaré', mostrando su propia dignidad. Después: 'Él vendrá': este es el poder (exousía) del Espíritu $(31,26)$

(221) 31,27

(222) Enumera los siguientes: Espíritu de Dios, Espíritu de Cristo, noûs de Cristo, Espíritu del Señor, Señor, Espíritu de adopción, de verdad, de libertad. Espíritu de sabiduría, de entendimiento, de consejo, de fuerza, de conocimiento, de piedad, de temor de Dios. Hacedor de todo, que todo lo llena con su ser (ousía $\mathbf{i}_{\mathrm{i}}$ ), que sostiene (sunéjon) todo. Llena el mundo con su ser (katà tèn ousían), no contenible por el mundo en cuanto su poder. Bueno, recto, conductor (hegemonikón), santificante por naturaleza y no por función dada (thései), no santificado, mide, no medido, se participa en Él, Él no participa, llena, no es llenado, sostiene, no sostenido. Recibido como herencia, glorificado, contado con [el Padre y el Hijo], amenazante. Dedo de Dios, fuego (como Dios, para demostrar que es homooúsios). Espíritu que crea, que recrea por el bautismo, por la resurrección. Espíritu que conoce todo, que enseña, que sopla donde y cuanto quiere, que guía, que habla, que envía, que aparta, que se irrita, que es tentado, que revela, que ilumina, que vivifica, más bien que es el mismo luz y vida. Nos hace templos, diviniza, nos conduce a la perfección, de manera que precede al bautismo y es buscado después del bautismo. Hace cuanto hace Dios, se divide en lenguas ígneas, distribuye los carismas, haciendo apóstoles, profetas, evangelistas, pastores y maestros. Inteligente, múltiple, claro, penetrante, irresistible, 
(223), etc., hay que referirlo a la causa primera para mostrar de quién viene y no se reciban tres principios divididos politeísticamente (224). A la objeción de que el Espíritu ha sido hecho por el Hijo según Jn 1, 3, responde Gregorio que ese hápanta no está dicho absolutamente (haplôss), puesto que no comprende al Padre (225).

Vista esta gran objeción de la Escritura y la prueba respectiva, pasemos ahora al resto de la discusión sobre la divinidad del Espíritu. ¿El Espíritu es de los que subsisten por sí mismo (substancia) o de los que son observados en otro (accidente). Si es accidente, sería la actividad (enérgeia) de Dios. Si es actividad, es activada (energizada) y cesa cuando no. Pero entonces, ¿cómo se aflige y se irrita, etc., lo que corresponde al que se mueve y no al movimiento? Y si es substancia y no en torno a la substancia, o es creatura o es Dios. Si es creatura, ¿cómo creemos en Él y nos lleva a la perfección? (226). Viene, entonces, la objeción: o es inengendrado o engendrado. Por tanto, o dos sin principio o dos hijos o un hijo y un nieto. Pero Gregorio no acepta el dilema. Además, al medio, se da tò ekporeutón, introducido por nuestro Salvador. En cuanto procede del Padre, no es creatura; y en cuanto no es engendrado, no es hijo. $\mathrm{Y}$ en cuanto medio entre el inengendrado y el engendrado, es Dios. Esto es un misterio (227). Retorna, de nuevo, la objeción: ¿qué le falta al Espíritu para ser Hijo? Responde Gregorio que a Dios no falta nada. La diferencia de la manifestación o de la relación entre ellos ha hecho la diferencia en la designación de ellos. Tampoco le falta nada al Hijo para ser Padre y viceversa. Esos términos no expresan carencia ni inferioridad según la substancia. El no ser engendrado, el ser engendrado y el proceder (tò ekporeúesthai) designan al Padre, al Hijo y al Espíritu Santo para que así sea salvada la no confusión de las tres hipóstasis en la única naturaleza y dignidad de la divinidad (228). Luego el Espíritu es consubstancial, puesto que es Dios. Gregorio trata de dar

inmaculado, lo que es decir, sapientísimo, multiforme en sus operaciones, aclara e ilumina todo, y dueño de sí mismo e inmutable. Que todo lo puede, supervisa, que penetra a través de todos los espíritus inteligentes, puros, sutilísimos -pienso que de los poderes angélicos-, como también de los proféticos y apostólicos, y al mismo tiempo y no en los mismos lugares, lo que muestra que nada lo circunscribe $(31,29)$. Algunos lo llaman otro Paráclito, como diciendo otro Dios; la blasfemia contra Él es la única imperdonable; mentirle al Espíritu Santo es como mentirle a Dios $(31,30)$. Véase, p. e. Orat $41,9$.

En 31, 20, a propósito de los números, dice, en un argumento ad hominem, que, por la igual dignidad de naturaleza (isotimían tês fúseos) de los tres, la Escritura no tiene un orden fijo para presentarlos. Igualmente, las palabras 'Dios y Señor', y las preposiciones 'de quien, por quien y en quien' son aplicadas a todos.

Al comienzo de este discurso $(31,2)$ dice que deja a otros (que ya lo han hecho: pefilosofékasin) el cuidadosamente investigar y distinguir de cuántas maneras es concebido y dicho en la Escritura Pneûma y hágion y qué significa su conjunción. Cf. 31, 21. Sobre la actividad del Espíritu en general, puede verse Bergmann, op. cit., 210-227.

(223) Ser enviado, distribuido (merízesthai), el carisma, el don, la insuflación, la promesa, la intercesión.

(224) 31,30

(225) 31, 12. El Espíritu estaría hecho por Cristo solo en la hipótesis de ser hecho.

(226) 31,6 .

(227) 31, 7s. Si le dicen lo que es lo ingénito del Padre, él explicará (fusiologésó) la generación del Hijo y la procesión (ekpóreusin) del Espíritu. Pero esto sería caer en la locura.

(228) 31, 9. "Porque ni el Hijo es el Padre, pues hay un solo Padre, pero es lo que es el Padre. Ni el Espíritu es el Hijo, por venir de Dios, pues hay un solo Unigénito, pero es lo que es el Hijo. Los tres son uno en la divinidad, y lo uno es tres en las propiedades, para que lo uno no sea lo de Sabelio, ni los tres lo de la perversa división de hoy" $(31,9)$. Cf. p. e. Ep 101, 20s. 
ejemplos de venir del mismo ser, como engendrado y como no engendrado, y de ser consubstanciales. Así son de la misma substancia Adán, Eva y Set, habiendo venido a la existencia de diferentes maneras. Eva y Set vienen de Adán, y uno es engendrado; la otra, no. Por tanto, se puede no ser engendrado y ser consubstancial. Esto es como contemplar en la escena del teatro lo pensado. Pero una comparación no alcanza toda la verdad en su pureza (229).

\section{CONCLUSIÓN}

Lo primero que me resalta es el momento teológico de Gregorio, que no parece ser muy diferente del de Agustín. Este es el de la divinidad del Espíritu, que defiende ardorosamente. Pero afirmar la divinidad del Espíritu, es afirmar la divinidad completa, la Trinidad. Se produce así un deslumbramiento trinitario, cuyos polos son: por un lado, los tres y, por otro, la única divinidad, única substancia y naturaleza. "Cuando, pues, por una parte miramos a la divinidad y a la causa primera y a la monarquía, se nos aparece lo uno, pero cuando miramos hacia aquellos en los que está la divinidad y los que vienen de la primera causa atemporalmente y con igual gloria, adoramos a tres" $(31,14)$.

Este es el misterio, dentro del cual Gregorio mantiene que el Padre es mayor en cuanto causa (de Él viene el Hijo), pero no en cuanto substancia, porque los tres son consubstanciales, son la única y misma divinidad. Como en tres soles que se compenetran mutuamente, única es la fusión (súgkrasis) de la luz. El Padre es el agénnetos, ánarjos y anaítios, respecto al Hijo y al Espíritu. Pero en cuanto la divinidad, Dios, es anaítios y ánarjos respecto a la creación, también del Hijo se puede decir anaitíos y anárjos, en cuanto eterno. El Espíritu es el que 'procede' (ekporeúetai), también proelthón y proïón, es el próblema del proboleús, que es el Padre. El Hijo es engendrado, pero no es ekporeuómenos. Es decir, agénnetos, gennetós y ekporeuómenon, son las propiedades respectivas de las hupotáseis (230). Lo uno es tres en las propiedades. Pero la única substancia no se divide, porque las propiedades (idiótetes) no son nombre de substancia, sino están en torno a la substancia (perì ousían). Son un nombre de relación, de cómo se tiene uno respecto al otro. La doctrina de la relación tendrá un enorme futuro en la presentación del misterio trinitario. Agrega Gregorio: como la substancia es una y todo viene

(229) 31, 10s.

(230) Según mi parecer, la polémica contra Eunomio debe haber contribuido bastante a que Gregorio centrara lo propio del Padre en la agennesía y no tanto en la paternidad. Esto quizás señala una diferencia con Agustín, quien es un poco posterior y estaría más centrado en las relaciones mutuas y en la unidad de la esencia divina. Agustín, que demora 20 años en escribir un tratado sobre la Trinidad, razona más a fondo (p. e. respecto a las relaciones), busca con mucho empeño imágenes de la Trinidad en el hombre y pone una relación entre el Hijo y el Espíritu cristalizada en el Filioque, siendo el Espíritu el amor entre el Padre y el Hijo. Las formulaciones de Gregorio en torno al misterio (teología negativa, también en oposición a Eunomio) nos pueden parecer más brillantes. En cierto sentido fue más retórico. Las fórmulas cristológicas de Agustín, que pertenecen a una generación posterior y a la cultura latina cristiana, son más maduras. Sobre Agustín, se puede consultar, S. Zañartu, Algunos aspectos de la visión de Agustín sobre Dios, Teología y Vida 39 (1998) 270-287. 
del Padre y hacia Él se vuelve, no se trata de una poliarquía sino de una monarquía. La monarquía dice distinción y unidad: igual dignidad de naturaleza y acuerdo del querer. Y mantiene que, de entre los tres consubstanciales relacionados, el Padre es el más grande, en cuanto causa.

Qué cosa sea la substancia de Dios es incognoscible para el hombre en esta tierra. Por tanto, agénneton no es el nombre de ella sino del Padre. El Espíritu es divino porque nos diviniza, porque lo adoramos, porque su divinidad está implícita en la Escritura. En cambio, la divinidad del Hijo aparece claramente en el Nuevo Testamento. Porque la revelación es progresiva, y, justamente, misión del Espíritu es aclararnos su propia divinidad. Por tanto, el problema del Espíritu, tal como lo plantean los herejes, no es que se aclare que es un otro distinto del Padre y del Hijo, sino que se aclare que como distinto es también Dios. En ese sentido es la prolongación de la polémica sobre el Hijo. Y la herejía que ataca la divinidad del Espíritu como triteísmo, aceptando la del Hijo, ¿cómo se defiende ella del diteísmo? A la Trinidad no se le puede quitar nada: sería combatir contra la divinidad. No hay Dios sin Logos y sin Espíritu Santo. Esta es la fe del bautismo, en la que uno se salva. Ataca a los herejes como palabreros, dialécticos e impíos, manifestando a la vez una buena capacidad lógica y una buena formación para refutar sus argumentos (231).

(231) Afirma Norris (op. cit., 182): Logical principles, grammatical rules and rhetorical practises are employed to demonstrate both the later Arians' lack of education and their misunderstanding of theology. Y respecto a la Orat 31, declara: In this oration more than the others, the ontological disagreements are mentioned, but they are as ever based in the understanding of language, in the relationship between names and essences, and are not given detailed explanation. Y añade, más adelante $(I b ., 195 \mathrm{~s})$ : The best description of his work is that of a philosophical rhetorician who can use ontological categories, but who prefers to handle the debate on the level of logical, grammatical principles. Much of the time he points out the fallacies in his opponents' reductionistic definitions and offers only sketches of his own confessions. He does that because he believes God is incomprenhensible in essence but at the same time knowable. Y al terminar su comentario a la Orat 31, opina lo siguiente: Once again his education as a philosophical rhetorician comes to the fore. He challenges their understanding of names and realities, their grasp of words and grammatical structures, and their absurd sense of counting and the nature of things counted. He rejects their understanding of the theologian's task and work within his own sense of calling. The major weaknesses of his position and approach are three. First, he does not describe a relationship between primal cause and Trinity that withstands scrutiny. At the confessional level it is sound because it holds together a number of Biblical statements, but at the logical or philosophical level it appears to be arbitrary. At least he should have given a richer explanation of his position. Second, he attacks his opponents for positing dual alternatives that exclude middle terms and yet employs the same procedure himself. To be persuasive, he would have to reformulate his attack in terms of specific concepts rather then employing a method he denies to his adversaries. Third, his appeal to a particular soteriological and litugical tradition stumbles because his antagonists do not claim that tradition. He needs to offer more support for his understanding of théosis,'deification', and worship rather than simply affirm them. Respecto a su primera debilidad no estoy del todo de acuerdo. Respecto a algunas influencias sobre Gregorio, Norris afirma en la introducción (Ib., 37s): "Yet the Theologian's dependence upon Aristotle's understanding of the relationship between logical syllogisms and rhetorical enthymemes seldom if ever appears as clearly in earlier Christian literature. Gregory relies on the Stagirite for the development of doctrine in terms of a faith response to questions of probability and an inductive rhetorical approach to theological argument and exegesis. His occasional use of Stoic logic and his partial acceptance of an Epicurean view of language fit well with his employment of Hermogenian rhetoric and his dependece upon an Aristotle who views arguments in terms other than syllogistic inference". 
Pasando a la divinidad de Cristo, dice que en Él diferenciamos dos naturalezas y así distingue los dichos que condicen con su divinidad y los que hay que atribuir a su humanidad. Pese a un lenguaje a ratos claramente antioqueno, contrastando los dichos, los atribuye con admiración al mismo sujeto. El Logos que unge es llamado hombre y el ungido es llamado Dios. Así los nombres se intercambian por causa de la mezcla. Es decir, da por descontado que Cristo es uno solo (232) (mezcló la forma divina con la imagen de esclavo), nacido de la Theotókos según la carne. Por tanto, engendrado según su generación primera y creado según su generación de aquí abajo. Haciéndose hombre nos hace a nosotros Dios. Asociándose a la carne por medio del noûs, es cuerpo, alma y espíritu, con pasiones carnales salvo el pecado, para liberar todo de la condenación. Nos lleva a nosotros con todo lo nuestro, para consumir lo peor como el fuego a la cera. Su querer no era opuesto a Dios, estando íntegramente divinizado. Es el Dios pasible por nosotros. Muere, pero vivifica y destruye la muerte con su muerte. Es enterrado, pero resucita. "Jesucristo ayer y hoy corporalmente, él mismo espiritualmente y por los siglos. Amén” $(30,21)$

\section{RESUMEN}

El autor presenta la doctrina trinitaria de Gregorio en forma maciza y concisa usando todo el material de los cinco discursos teológicos, lo que no impide algunas referencias a otros textos significativos de Gregorio, a modo de ejemplo. Al comienzo trata del no conocimiento del hombre respecto a qué es la naturaleza propia de Dios, contra Eunomio. Al afirmar la divinidad del Espíritu (consubstancial), Gregorio queda deslumbrado por los dos polos: el de la unidad (naturaleza) y el de los tres (propiedades). Estas no dividen la substancia porque se hallan en torno a ella, son relación. Así se mueve entre la desviación de Sabelio y la de los arrianos, defendiendo el misterio de la Trinidad recibido en el bautismo. El autor del artículo va resumiendo las objeciones y las respuestas, ofreciéndonos una equilibrada presentación de conjunto. Cree que el momento teológico de Gregorio no estaría muy distante del de Agustín.

\section{ABSTRACT}

St. Gregory's Trinitarian doctrine is concisely presented using the whole of the material of the five theological speeches, together with some references of other significant texts written by him. At the beginning, the article deals with Man's non-knowledge about God's own nature, as opposed to Eunomio. When Gregory asserts the (consubstancial) divinity of the Spirit, he is dazzled by both poles: on the one hand, the unity of God (nature) and on the other his trinity (properties). These do not destroy the substance because they exist around it; they are relations. So, he fluctuates between Sabelius' divergence and the Arrian's, defending the mystery of the church received at baptism. The author offers an overall balanced presentation, summarising the objections and their responses. He believes Gregory's theological moment would not be too distant from Augustine's.

(232) Cf. p. e. Ep 101, 13-21. El hombre no fue formado primero. "La nueva mezcla, Dios y hombre; y uno de ambos y por uno ambos" (Orat 2, 23). Según comentario de Althaus (op. cit., 132), "Die Behauptung der Verschiedenheit der Naturen nach der Einigung entsprach dem Dyophysitismus, aber die vom eigenen Heilsziel geforderte Vergöttlichung der menschlichen Natur Christi durch die göttliche strebte mit innerer Logik zum Monophysitismus". 